\title{
The impact of business and political news on the GCC stock markets ${ }^{\star}$
}

\author{
Alanoud Al-Maadid ${ }^{\mathrm{a}}$, Guglielmo Maria Caporale ${ }^{\mathrm{b}, *}$, Fabio Spagnolo ${ }^{\mathrm{b}}$, \\ Nicola Spagnolo ${ }^{\mathrm{b}, \mathrm{c}}$

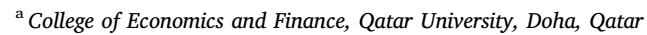 \\ ${ }^{\mathrm{b}}$ Department of Economics and Finance, Brunel University London, UK \\ ${ }^{\mathrm{c}}$ Centre for Applied Macroeconomic Analysis (CAMA), Australian National University, Australia
}

\section{A R T I C L E I N F O}

\section{JEL classification:}

C32

F36

G15

\section{Keywords:}

Business news

GCC countries

Markov switching Model

Political news

\begin{abstract}
A B S T R A C T
This paper investigates the impact of business and political news on stock market returns in the Gulf Cooperation Council (GCC) countries. For this purpose, it employs a Markov switching model including a separate index for each of the two categories of news considered. The results indicate the importance of news as drivers of GCC stock returns, with business news playing a more substantial role; further, news released in the largest financial markets in the regions are found to have significant cross-border effects.
\end{abstract}

\section{Introduction}

The effects of macroeconomic news on stock prices have been analysed extensively in the more recent financial literature. The theoretical motivation comes from asset pricing models according to which factors driving macro series such as consumption and investment should also affect asset prices (e.g., Merton, 1973). Information clearly plays a crucial role in financial markets (Strycharz et al., 2018; Tetlock, 2007). Financial news, market announcements, corporate news, and analyst forecasts affect the expectations of investors and might generate high volatility in stock markets. Numerous studies have analysed their impact on stock returns (Lavrenko et al., 2000; Chan, 2003; Andersen et al., 2007; Tetlock et al., 2008; Nartea et al., 2009; Alfarano et al., 2011). The World Bank, Annual Report 2017; Cutler et al. (1989) estimated that macroeconomic news explain approximately one-third of the variance of stock returns whilst financial news have limited predictive power for returns. Birz and Lott (2011) focused on the impact of newspaper headlines on the US stock market, whilst Caporale et al. (2016, 2018a,b) assessed their impact on European stock and bond markets and the FOREX in emerging markets respectively. Studies in behavioural finance have addressed the possibility of human emotions influencing investment decisions (De Long et al., 1990; Shleifer and Vishny, 1997) and found that the prevailing sentiment in financial reports or news articles affects stock returns (Li, 2006 and Schumaker et al., 2012).

Most of the above papers focus on the developed countries or on a small subset of the emerging economies. There is instead hardly

\footnotetext{
${ }^{\star}$ We would like to thank the Editor and two anonymous referees for very helpful comments and suggestions. The first author would also like to thank Qatar University for financial support, Grant no. QUCP-CBE-2018-1. The findings are solely the responsibility of the authors.

* Corresponding author at: Department of Economics and Finance, Brunel University London, UB8 3PH, UK.

E-mail address: Guglielmo-Maria.Caporale@brunel.ac.uk (G.M. Caporale).
} 
any evidence concerning the members of the Gulf Cooperation Council (GCC) that was established in 1981 (namely, Bahrain, Qatar, Kuwait, Oman, UAE and Saudi Arabia). These are currently classified as emerging countries engaged in the transformation of their economies through the creation of new industry segments and diversification (Shkvarya and Frolova, 2017). The GCC average annual GDP per capita $(\$ 69,166)$ is substantially higher than the world average $(\$ 16,961)$ as reported by the World Bank $(2017)$. Its members have benefited from being oil and gas producers, although they have still been affected by the worldwide slowdown caused by the 2007-8 global financial crisis. Market capitalisation in 2017 was USD451bn in Saudi Arabia, USD132bn in Abu Dhabi, USD130bn in Qatar, USD104bn in Dubai, USD90bn in Kuwait (and slightly lower in Bahrain and Oman). The GCC has recently launched a series of common economic projects to promote integration. However, diplomatic tensions between its member states persist. The latest episode occurred in June 2017, when the main index for the Qatar Stock Exchange dropped by 6.38 per cent amid growing tensions with some neighbouring Gulf states; in particular, Bahrain, Saudi Arabia and the UAE cut their diplomatic relations with Qatar, whilst Kuwait and Oman remained neutral.

An important study by Al-Kindi (2016) applies Media Authoritarian Theory to analyse the media - government relationship in the GCC group. He argues that mass media in these countries were targeted to reform the Arab World in general, and the GCC group in particular. The measures taken included media leadership change, media policies and rules change, and granting greater freedom of expression, with the aim of replacing "government" media with "state" media. Aday et al. (2012) had previously found that the new media outlets had played an important role in the Arab Spring by spreading information widely across the region.

Ahmed (2011) documented a high degree of market integration within the GCC. Alodayni (2016) estimated a panel VAR to investigate the linkages between the GCC banking system and the real economy. The results show that macro-economic variables, such as the oil price, non-oil GDP, interest rates, stock prices, and housing prices are major determinants of profit and loss for GCC banks. The high degree of dependence of the GCC countries on oil revenues makes them particularly vulnerable to external shocks that could threaten their financial stability; they have therefore built up financial buffers in order to attenuate the impact of fluctuations in international oil prices; moreover, their low debt to GDP ratio also gives them room for fiscal manoeuvring consistent with long-run sustainability.

This paper aims to shed new light on the impact of (negative) business and political news obtained from Bloomberg on GCC stock returns. Similarly to Caporale et al. (2016, 2018a,b) it focuses on the effects of newspaper coverage of such news. However, unlike those studies, the current one adopts a non-linear, Markov-switching econometric framework. Its advantage is that it can distinguish between periods of low and high returns (volatility) respectively; in other words, causality linkages are not constrained to be constant across phases of the economic cycle (i.e. news are allowed to affect stock returns differently in periods of boom and bust) and in different regimes (i.e. news can have a different impact in periods of low and high returns). The adopted specification also controls for news surprises, monetary policy and financial globalisation. In brief, the analysis reveals some interesting differences between the financial markets of the core and peripheral (GCC) countries in the way they respond to news.

The layout of the paper is as follows. Section 2 outlines the econometric model. Section 3 describes the data and discusses the empirical results. Section 4 summarises the main findings and offers some concluding remarks.

\section{The model}

As already mentioned, in order to analyse the dynamic linkages between (political and business) newspaper news and stock market returns we estimate a regime-switching model ${ }^{1}$ allowing for shifts in both the mean and the variance parameters measuring the impact of news in periods of low/high stock market returns and volatilities; the specification is the following:

$$
\begin{aligned}
& r_{i, t}=\mu\left(s_{t}\right)+\sum_{m=1}^{2} \phi_{m} r_{i, t-m}+\alpha\left(s_{t}\right) \mathrm{NPN}_{j, t-1}+\beta\left(s_{t}\right) \mathrm{NBN}_{j, t-1}+\operatorname{Control}_{i, t-1}+\sigma\left(s_{t}\right) \varepsilon_{t}, \varepsilon_{t} \sim N(0,1) \\
& \mu\left(s_{t}\right)=\sum_{k=\text { low }}^{\text {high }} \mu^{(k)} \mathbf{1}\left\{s_{t}=k\right\}, \quad \alpha\left(s_{t}\right)=\sum_{k=\text { low }}^{\text {high }} \alpha^{(k)} \mathbf{1}\left\{s_{t}=k\right\}, \\
& \beta\left(s_{t}\right)=\sum_{k=\text { low }}^{\text {high }} \beta^{(k)} \mathbf{1}\left\{s_{t}=k\right\}, \quad \sigma\left(s_{t}\right)=\sum_{k=\text { low }}^{\text {high }} \sigma^{(k)} \mathbf{1}\left\{s_{t}=k\right\}, \quad(t \in \mathbb{T})
\end{aligned}
$$

where $r_{i, t}=$ logarithmic change of stock market indexes $i, \mathrm{NPN}_{j, t-1}=$ negative political news in country $j$, NBN $\mathrm{N}_{j, t-1}=$ negative business news in country $j$. A set of control variables is also included, namely domestic macro news surprises, oil prices, domestic interest rates and the VIX as a proxy for global stock market volatility. Given the fact that $s_{t}$ is unobserved, the estimation of (1) requires restrictions on the probability process governing it; specifically, it is assumed that $s_{t}$ follows a first-order, homogeneous, two-state Markov chain. Therefore, the regime indicators $\left\{s_{t}\right\}$ are assumed to form a Markov chain on $\mathbb{S}$ with a transition probability matrix $\mathbf{P}^{\prime}=\left[p_{\text {low, high }}\right]_{2 \times 2}$, where:

$$
p_{\text {low, high }}=\operatorname{Pr}\left(s_{t}=\operatorname{high} \mid s_{t-1}=\text { low }\right), \quad \text { low, high } \in \mathbb{S},
$$

and $p_{\text {low,low }}=1-p_{\text {low,high }}(i \in \mathbb{S})$, where each column sums to unity and all elements are non-negative. The probability law that governs these regime changes is flexible enough to allow for a wide variety of shifts, depending on the values of the transition probabilities. For example, values of $p_{\text {low,low }}($ low $\in \mathbb{S}$ ) that are not very close to unity imply that the structural parameters are subject

\footnotetext{
${ }^{1}$ The model is based on the Markov switching representation proposed by Hamilton (1989, 1990).
} 

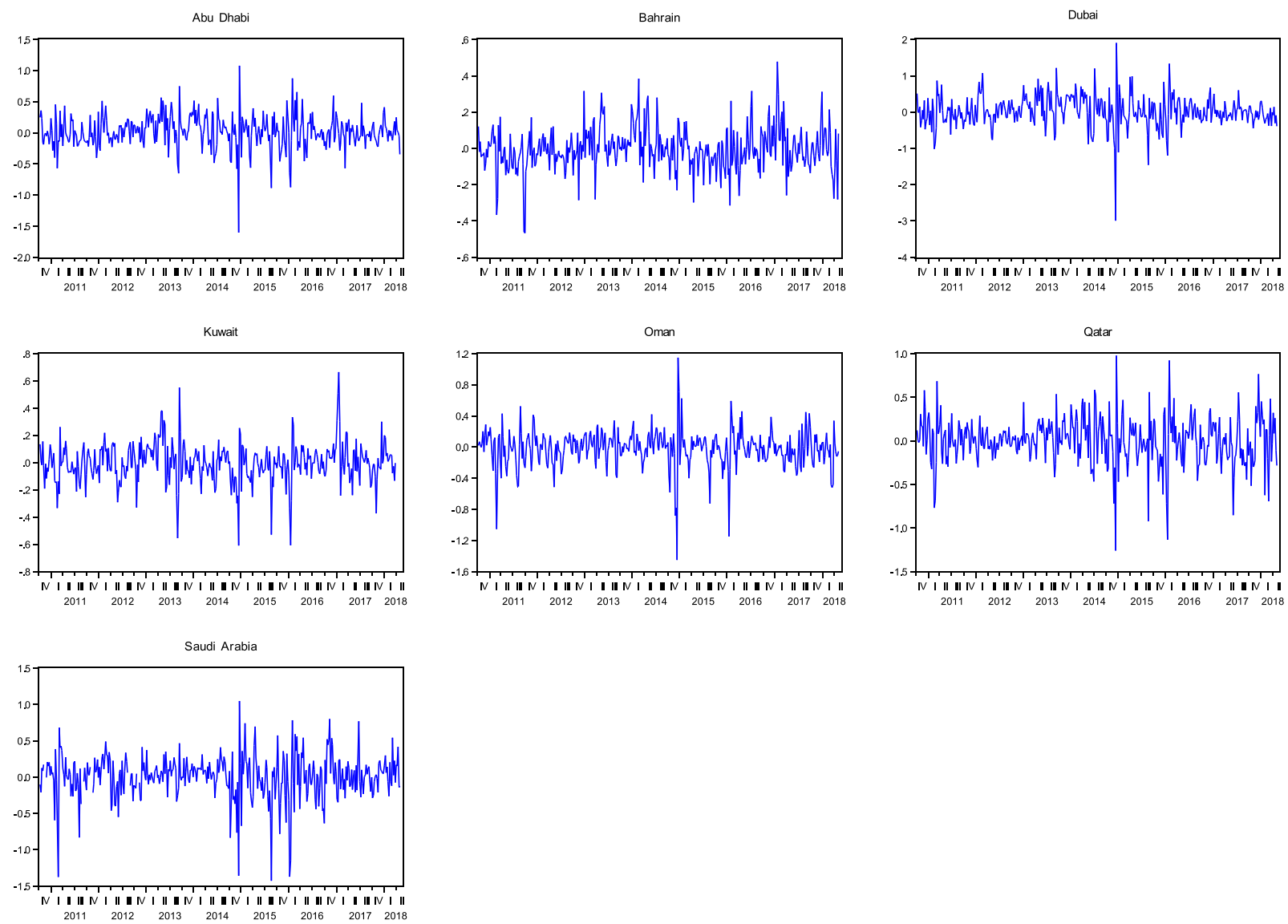

Fig. 1. GCC stock market returns. Note: Stock returns in country $i$ are the weekly returns of the stock market index for country $i$ at time $t$. It is calculated as $100^{*}\left(\left(\right.\right.$ Stock $_{i, t}-$ Stock $\left._{i, t-1}\right) /$ Stock $\left._{i, t-1}\right)$.

to frequent changes, whereas values near unity suggest that only a few regime transitions are likely to occur in a relatively short realization of the process (i.e. regime persistence). $\left\{\varepsilon_{t}\right\}$ are i.i.d. errors with $\mathrm{E}\left(\varepsilon_{t}\right)=0$ and $\mathrm{E}\left(\varepsilon_{t}^{2}\right)=1$. $\left\{s_{t}\right\}$ are random variables in $\mathbb{S}=\{1,2\}$ that indicate the unobserved state ${ }^{2}$ of the system at time $t$. It is assumed that $\left\{\varepsilon_{t}\right\}$ and $\left\{S_{t}\right\}$ are independent. Also, note that the independence between the sequences $\left\{\varepsilon_{t}\right\}$ and $\left\{s_{t}\right\}$ implies that regime changes take place independently of the past history of $\left\{r_{i, t}\right\}$.

The autoregressive lag length is selected according to the Schwarz Bayesian Criterion (SBC), allowing for up to two lags. Therefore, the parameter vector of the mean equation (1) is defined by $\mu^{(s)},\left(s=\right.$ low, high), and $\sigma^{(s)}$, (s = low, high), which are real constants, and the autoregressive terms $\sum_{m=1}^{2} \phi_{i}$, up to two lags. $\alpha=\left(\alpha^{l}, \alpha^{h}\right)$ and $\beta=\left(\beta^{l}, \beta^{h}\right)$ measure the impact of negative political news in country $j$ and negative business news in country $j$ respectively on stock market returns in country $i$. This vector is estimated by means of maximum likelihood. The density of the data has two components, one for each regime, and the log-likelihood function is constructed as a probability-weighted sum of these two components. The maximum likelihood estimation is performed using the EM algorithm described by Hamilton (1989, 1990).

For comparison purposes, we also estimate the standard linear model normally used in the literature, which we treat as a benchmark. This is given by:

$$
r_{i, t}=\mu+\sum_{m=1}^{2} \phi_{m} r_{i, t-m}+\alpha \mathrm{NPN}_{j, t-1}+\beta \mathrm{NBN}_{j, t-1}+\operatorname{Control}_{i, t-1}+\sigma \varepsilon_{t}, \quad \varepsilon_{t} \sim N(0,1)
$$

where the parameter vector of the mean equation (2) is defined by the constant parameters $\left(\mu, \phi_{m}, \alpha, \beta, \sigma\right)$.

\section{Empirical analysis}

\subsection{Data}

The series used for the estimation are negative political news $\left(\mathrm{NPN}_{t}\right)$, negative business news $\left(\mathrm{NBN}_{t}\right)$ and stock market returns $\left(r_{t}\right)$

\footnotetext{
${ }^{2}$ Regime 1 and 2 are labelled as the low and high regime respectively.
} 
Bahrain

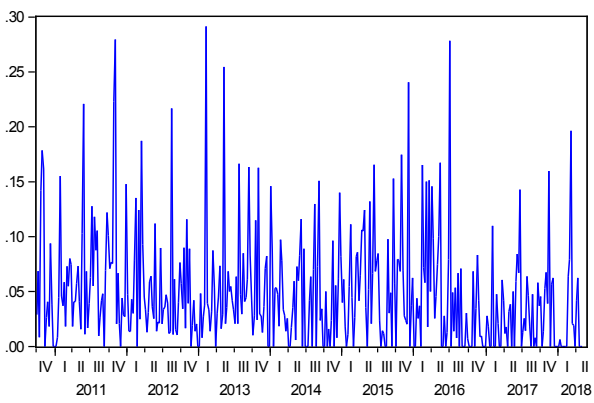

Oman

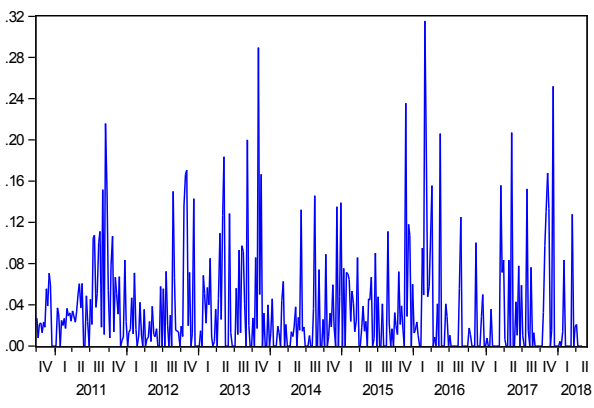

Saudi Arabia

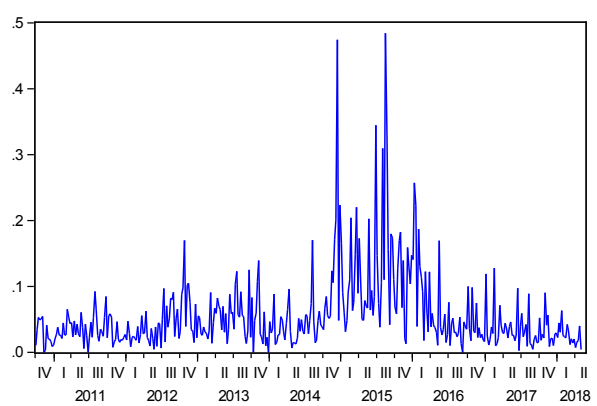

Kuwait
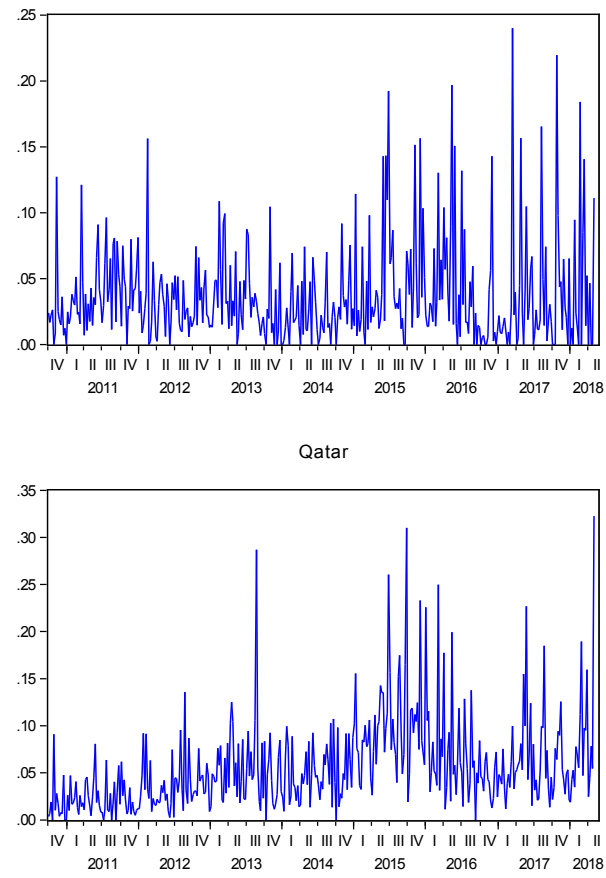

United Arab Emirates

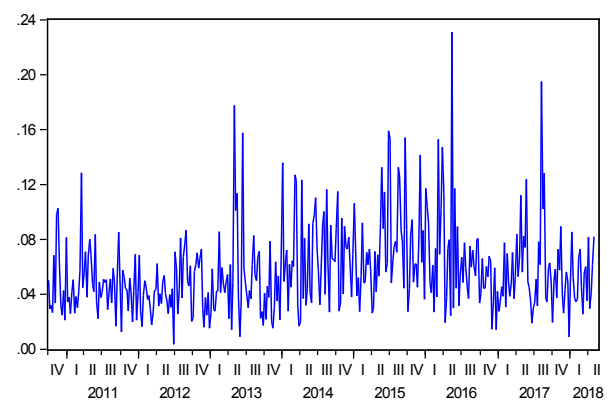

Fig. 2. Business news. Note: Business news coverage is proxied by story headlines counts. All business news (negative, positive, mixed and neutral) were first counted, then only negative business news were selected. The ratio of latter to former is the business negative news index. Therefore, the weekly negative business news percentage $\left(\mathrm{NBN}_{i, t}\right)$ is defined as (negative news)/All. (For interpretation of the references to color in the text, the reader is referred to the web version of this article.)

constructed from the stock market indices of seven GCC countries (Dubai, Abu Dhabi, Bahrein, Saudi Arabia, Kuwait, Oman and Qatar). The data are weekly and run from October 2010 to May 2018 for a total of 399 observations (the sample size reflects data availability for business and political news). The data source for stock market indices and the control variables is the IMF's International Financial Statistics (IFS), whereas data on political and business news are taken from Bloomberg. Weekly stock market returns are calculated as the percentage change in stock prices (Fig. 1).

Concerning the negative business (political) index, we first counted the number of all business (political) news stories, then the number of stories with a negative connotation only. ${ }^{3}$ The news variable in each case is an index defined as the ratio of the number of negative news headlines to the total number of headlines (see the blue line in Figs. 2 and 3 for business and political news respectively). Previous research has found that stock returns are sensitive to both negative and positive newspaper news; however negative news have more pronounced effects on returns (Veronesi, 1999; Tetlock, 2007; Wang et al., 2009; Caporale et al., 2018a). Therefore, in this paper, we focus on negative (political and business) news headlines as a percentage of the total. A week is defined as going from Wednesday to Wednesday in order to control for different weekends in the GCC and the US (for the VIX index). Oil prices are also included in first differences.

Furthermore, in line with the previous literature (Kim and Nelson, 1999; Simpson et al., 2005) we add macro news surprises to the

\footnotetext{
${ }^{3}$ These are classified by Bloomberg as "potentially negative news". Examples of negative business news and negative political news are available from the authors upon request.
} 

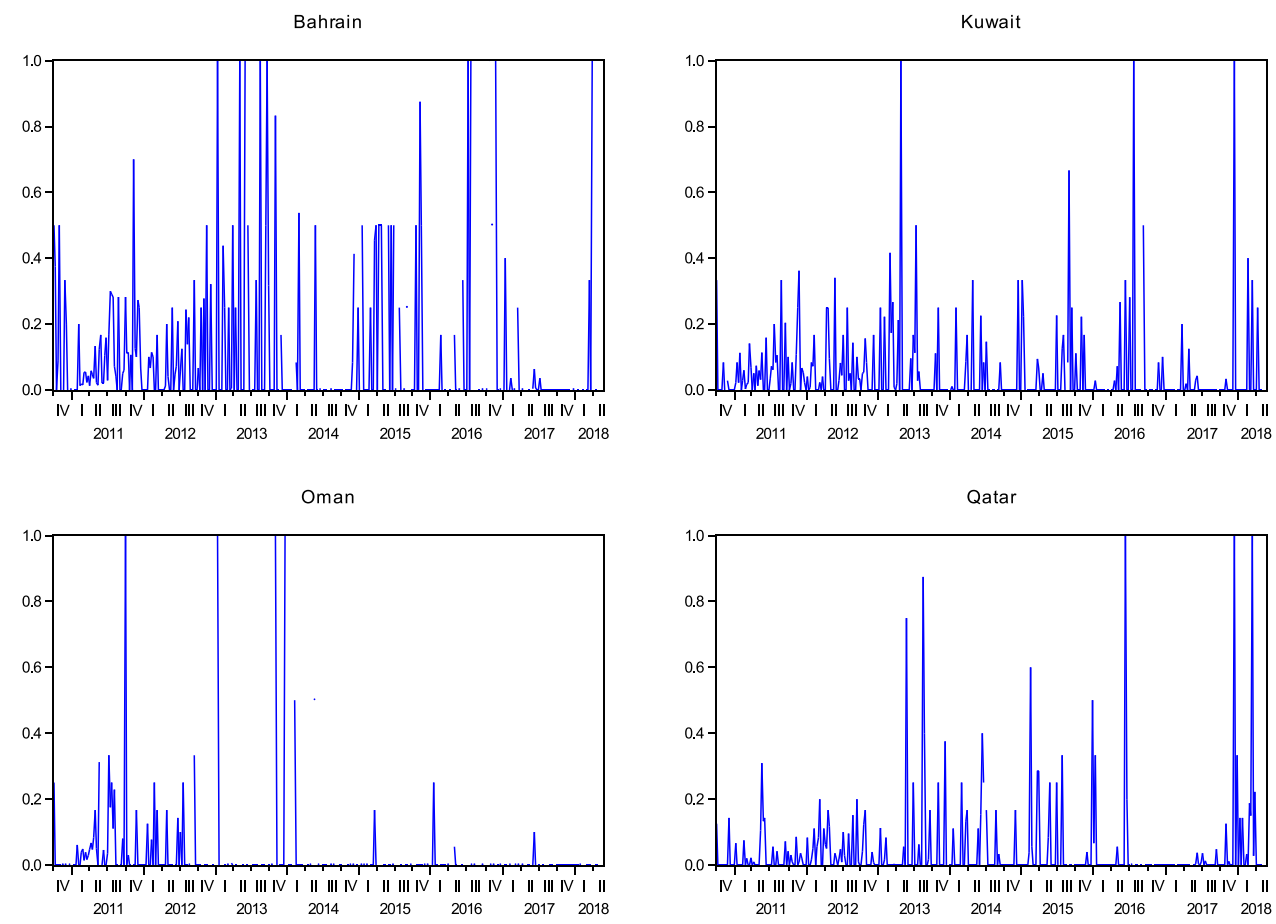

Saudi Arabia
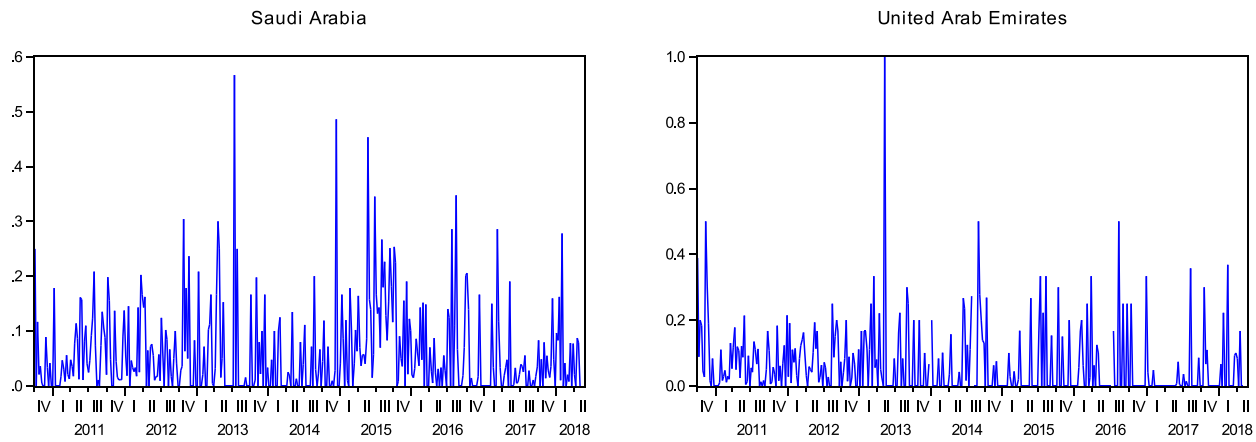

Fig. 3. Political news. Note: Political news coverage is proxied by story headlines counts. All political news (negative, positive, mixed and neutral) were first counted, then only negative political news were selected. The ratio of latter to former is the negative political news index. Therefore, the weekly negative political news percentage $\left(\mathrm{NPN}_{i, t}\right)$ is defined as (negative news)/All. (For interpretation of the references to color in the text, the reader is referred to the web version of this article.

set of variables. These are calculated as the difference between market expectations, obtained from Bloomberg's contributor composite, and the actual figures released, and are then standardised using the standard deviation of the macroeconomic surprise.

To summarise, the set of variables included in the model is the following: $r_{i, t}$ : Weekly returns of the stock market index for country $i$ at time $t$ calculated as $100^{*}\left(\left(\operatorname{Stock}_{i, t}-\operatorname{Stock}_{i, t-1}\right) /\left(\operatorname{Stock}_{i, t-1}\right)\right)$;

$\mathrm{NPN}_{i, t}$ : Negative political news as a percentage of total political news (i.e. positive, negative, mixed and neutral) in country $i$ at time $t$;

$\mathrm{NBN}_{i, t}$ : Negative business news as a percentage of total business news (i.e. positive, negative, mixed and neutral) in country $i$ at time $t$;

Oil $t_{t}$ : Oil price returns calculated as $100 *\left(\left(\right.\right.$ Brent $_{t}-$ Brent $\left._{t-1}\right) /\left(\right.$ Brent $\left.\left._{t-1}\right)\right)$, where Brent is the US Brent oil price;

Macro Surprises ${ }_{i, t}:$ Macro surprises calculated as $\left(\right.$ Actual $_{i, t}-$ Forecast $\left._{i, t}\right) / \sigma_{i}$ for country $i$ at time $t$, where $\sigma_{i}$ is the standard deviation of the macroeconomic surprise;

IntRate $_{i, t}$ : the 3-month deposit rate in country $i$ at time $t$;

$\mathrm{VIX}_{t}$ : a measure of the USA option-implied volatility at time $t$.

Summary statistics for these variables are displayed in Tables 1 and 2 . The mean weekly change for stock returns is positive for all countries but Bahrain, Kuwait and Oman. The Abu Dhabi and Dubai stock markets, followed by the Qatar and Saudi Arabia ones, are those with the highest returns. The standard deviation indicates that the highest volatility occurs in the case of Dubai (0.433); Abu Dhabi, Oman, Qatar and Saudi Arabia exhibit similar values ranging from 0.236 to 0.304; Bahrain and Kuwait have the lowest volatilities. The Jarque-Bera (JB) test statistics provide evidence of non-normality for all series. 
Table 1

Descriptive statistics.

\begin{tabular}{|c|c|c|c|c|c|c|c|}
\hline & \multicolumn{7}{|c|}{ Stock market returns } \\
\hline & Abu Dhabi & Bahrain & Dubai & KSA & Kuwait & Oman & Qatar \\
\hline Mean & 0.019 & -0.003 & 0.026 & 0.005 & -0.002 & -0.021 & 0.001 \\
\hline Max. & 1.089 & 0.477 & 1.902 & 1.049 & 0.655 & 1.151 & 0.978 \\
\hline Min. & -1.603 & -0.466 & -2.993 & -1.431 & -0.608 & -1.435 & -1.261 \\
\hline Std. Dev & 0.261 & 0.119 & 0.433 & 0.304 & 0.144 & 0.236 & 0.268 \\
\hline Skew & -0.561 & 0.146 & -0.701 & -1.057 & -0.115 & -0.936 & -0.462 \\
\hline Kurt. & 7.778 & 4.991 & 9.891 & 7.601 & 6.665 & 10.077 & 5.887 \\
\hline Prb.J-B & 0.000 & 0.000 & 0.000 & 0.000 & 0.000 & 0.000 & 0.000 \\
\hline
\end{tabular}

\begin{tabular}{|c|c|c|c|c|c|c|}
\hline & \multicolumn{6}{|c|}{ Business news } \\
\hline & Bahrain & KSA & Kuwait & Oman & Qatar & UAE \\
\hline Mean & 0.049 & 0.056 & 0.036 & 0.036 & 0.056 & 0.057 \\
\hline Max. & 0.291 & 0.484 & 0.239 & 0.315 & 0.322 & 0.231 \\
\hline Min. & 0.000 & 0.000 & 0.000 & 0.000 & 0.000 & 0.003 \\
\hline Std. Dev & 0.051 & 0.058 & 0.038 & 0.052 & 0.048 & 0.031 \\
\hline Skew & 1.754 & 3.318 & 2.074 & 2.205 & 2.125 & 1.561 \\
\hline Kurt. & 6.835 & 19.148 & 8.321 & 8.709 & 9.791 & 6.873 \\
\hline \multirow[t]{3}{*}{ Prb.J-B } & 0.000 & 0.000 & 0.000 & 0.000 & 0.000 & 0.000 \\
\hline & \multicolumn{6}{|c|}{ Political news } \\
\hline & Barhain & KSA & Kuwait & Oman & Qatar & UAE \\
\hline Mean & 0.095 & 0.059 & 0.044 & 0.035 & 0.046 & 0.053 \\
\hline Max. & 1.000 & 0.566 & 0.500 & 1.000 & 1.000 & 0.500 \\
\hline Min. & 0.000 & 0.000 & 0.000 & 0.000 & 0.000 & 0.000 \\
\hline Std. Dev & 0.175 & 0.073 & 0.083 & 0.128 & 0.129 & 0.077 \\
\hline Skew & 2.305 & 2.335 & 2.423 & 5.782 & 4.874 & 2.015 \\
\hline Kurt. & 8.701 & 12.913 & 9.191 & 40.913 & 31.621 & 9.041 \\
\hline Prb.J-B & 0.000 & 0.000 & 0.000 & 0.000 & 0.000 & 0.000 \\
\hline
\end{tabular}

Note: Stock market returns are the percentage changes in stock prices. News coverage is proxied by story headlines counts. News classified as potential negative were counted. Then All news (potentially negative and positive, mixed and neutral) were counted. The ratio of latter to former is the negative news index. Therefore, the weekly negative news percentage is defined as negative news/All. The sample size covers the period October 2010 to May 2018, for a total of 399 weekly observations.

Table 2

Descriptive statistics - control variables.

\begin{tabular}{|c|c|c|c|c|c|c|c|c|}
\hline \multicolumn{9}{|c|}{ Macroeconomic news surprises } \\
\hline & Bahrain & KSA & Kuwait & Oman & Qatar & \multicolumn{2}{|l|}{ UAE } & GCC \\
\hline Mean & 0.426 & -0.464 & 0.088 & -0.194 & -0.676 & \multicolumn{2}{|l|}{0.046} & -0.773 \\
\hline Max. & 2.407 & 1.689 & 2.479 & 2.610 & 0.208 & \multicolumn{2}{|l|}{2.026} & 5.466 \\
\hline Min. & -1.868 & -2.399 & -1.049 & -2.586 & -3.871 & \multicolumn{2}{|l|}{-1.624} & -6.601 \\
\hline Std. Dev & 0.927 & 0.875 & 0.808 & 0.818 & 0.947 & \multicolumn{2}{|l|}{0.806} & 2.280 \\
\hline Skew & 0.245 & 0.160 & 1.632 & 0.979 & -1.628 & \multicolumn{2}{|l|}{0.461} & -0.270 \\
\hline Kurt. & 0.166 & -0.243 & 2.421 & 2.378 & 2.461 & \multicolumn{2}{|l|}{-0.506} & 0.109 \\
\hline Prb.J-B. & 0.000 & 0.000 & 0.000 & 0.000 & 0.000 & \multicolumn{2}{|l|}{0.000} & 0.000 \\
\hline & \multicolumn{6}{|c|}{ Interest rates } & \multicolumn{2}{|l|}{ Others } \\
\hline & Bahrain & KSA & Kuwait & Oman & Qatar & UAE & VIX & Oil \\
\hline Mean & 1.517 & 2.010 & 1.126 & 1.415 & 4.753 & 1.381 & 2.753 & 2.820 \\
\hline Max. & 3.175 & 2.250 & 1.563 & 2.400 & 5.500 & 2.539 & 3.871 & 4.736 \\
\hline Min. & 1.000 & 2.000 & 0.625 & 1.000 & 4.500 & 0.677 & 2.213 & 0.000 \\
\hline Std. Dev & 0.564 & 0.049 & 0.324 & 0.493 & 0.366 & 0.537 & 0.288 & 2.033 \\
\hline Skew & 1.484 & 4.644 & 0.208 & 0.498 & 1.100 & 0.478 & 0.891 & -0.629 \\
\hline Kurt. & 1.145 & 19.584 & -1.278 & -1.519 & -0.273 & -0.855 & 1.036 & -1.530 \\
\hline Prb.J-B & 0.000 & 0.000 & 0.000 & 0.000 & 0.000 & 0.000 & 0.000 & 0.000 \\
\hline
\end{tabular}

Note: The sample size covers the period October 2010 to May 2018, for a total of 399 weekly observations. 
Table 3

Correlations.

\begin{tabular}{|c|c|c|c|c|c|c|c|}
\hline & \multicolumn{7}{|c|}{ Stock market returns } \\
\hline & Abu Dhabi & Bahrain & Dubai & KSA & Kuwait & Oman & Qatar \\
\hline Abu Dhabi & 1 & 0.264 & 0.841 & 0.505 & 0.481 & 0.543 & 0.636 \\
\hline Bahrain & 0.265 & 1 & 0.319 & 0.191 & 0.414 & 0.278 & 0.281 \\
\hline Dubai & 0.841 & 0.319 & 1 & 0.561 & 0.531 & 0.578 & 0.649 \\
\hline KSA & 0.505 & 0.191 & 0.561 & 1 & 0.414 & 0.448 & 0.514 \\
\hline Kuwait & 0.481 & 0.414 & 0.531 & 0.414 & 1 & 0.416 & 0.448 \\
\hline Oman & 0.543 & 0.278 & 0.578 & 0.448 & 0.416 & 1 & 0.495 \\
\hline Qatar & 0.636 & 0.281 & 0.649 & 0.514 & 0.448 & 0.495 & 1 \\
\hline
\end{tabular}

\begin{tabular}{|c|c|c|c|c|c|c|}
\hline & \multicolumn{6}{|c|}{ Business news } \\
\hline & Bahrain & KSA & Kuwait & Oman & Qatar & UAE \\
\hline Bahrain & 1 & 0.109 & 0.247 & 0.242 & 0.105 & 0.144 \\
\hline KSA & 0.109 & 1 & 0.127 & 0.093 & 0.374 & 0.358 \\
\hline Kuwait & 0.247 & 0.127 & 1 & 0.261 & 0.308 & 0.274 \\
\hline Oman & 0.242 & 0.093 & 0.261 & 1 & 0.185 & 0.194 \\
\hline Qatar & 0.105 & 0.374 & 0.308 & 0.185 & 1 & 0.477 \\
\hline \multirow[t]{3}{*}{ UAE } & 0.144 & 0.358 & 0.274 & 0.194 & 0.477 & 1 \\
\hline & \multicolumn{6}{|c|}{ Political news } \\
\hline & Barhain & KSA & Kuwait & Oman & Qatar & UAE \\
\hline Bahrain & 1 & 0.182 & 0.264 & 0.436 & 0.193 & 0.124 \\
\hline KSA & 0.182 & 1 & 0.349 & 0.158 & 0.029 & 0.179 \\
\hline Kuwait & 0.264 & 0.349 & 1 & 0.276 & 0.294 & 0.121 \\
\hline Oman & 0.436 & 0.158 & 0.276 & 1 & 0.112 & 0.201 \\
\hline Qatar & 0.193 & 0.029 & 0.294 & 0.112 & 1 & 0.033 \\
\hline UAE & 0.124 & 0.179 & 0.121 & 0.201 & 0.033 & 1 \\
\hline
\end{tabular}

Note: Correlations statistics are reported. The sample size covers the period October 2010 to May 2018, for a total of 399 weekly observations.

Table 4

Linear OLS - summary results.

\begin{tabular}{|c|c|c|c|c|c|c|c|c|c|c|c|c|}
\hline \multirow{2}{*}{$\begin{array}{l}\text { Effects from } \\
\text { Effects to }\end{array}$} & \multicolumn{2}{|c|}{ Bahrain news } & \multicolumn{2}{|c|}{ KSA news } & \multicolumn{2}{|c|}{ Kuwait news } & \multicolumn{2}{|c|}{ Oman news } & \multicolumn{2}{|c|}{ Qatar news } & \multicolumn{2}{|c|}{ UAE news } \\
\hline & Bus. & Pol. & Bus. & Pol. & Bus. & Pol. & Bus. & Pol. & Bus. & Pol. & Bus. & Pol. \\
\hline Bahrain & $(+)$ & $(+)$ & $(-)^{*}$ & $(+)^{*}$ & $(-)^{*}$ & $(+)$ & $(-)^{*}$ & $(+)$ & $(+)$ & $(+)$ & $(-)^{*}$ & $(-)^{*}$ \\
\hline KSA & $(+)$ & $(-)$ & $(-)^{* * * *}$ & $(+)^{*}$ & $(-)$ & $(+)$ & $(+)$ & $(-)$ & $(-)^{* * * *}$ & $(-)$ & $(-)^{* * * *}$ & $(+)$ \\
\hline Kuwait & $(-)$ & $(-)$ & $(-)^{* * *}$ & $(+)^{*}$ & $(-)^{* * *}$ & $(+)$ & $(-)^{*}$ & $(+)$ & $(-)^{* * *}$ & $(-)^{* * *}$ & $(-)^{* * *}$ & $(+)^{* * * k}$ \\
\hline Oman & $(-)$ & $(-)$ & $(-)^{* * * *}$ & $(+)^{* * *}$ & $(-)$ & $(+)$ & $(-)$ & $(+)$ & $(-)^{*}$ & $(-)^{* *}$ & $(-)$ & $(+)$ \\
\hline Qatar & $(-)$ & $(+)$ & $(-)^{* * * *}$ & $(+)$ & $(-)^{*}$ & $(+)$ & $(-)$ & $(-)(-)$ & $(-)^{* * * *}$ & $(+)^{* * *}$ & $(-)^{* * *}$ & $(+)$ \\
\hline UAE (Abu Dhabi) & $(-)$ & $(-)$ & $(-)^{* *}$ & $(+)^{*}$ & $(+)$ & $(+)$ & $(-)$ & $(+)$ & $(-)^{* * *}$ & $(+)$ & $(-)^{* * *}$ & $(+)$ \\
\hline UAE (Dubai) & $(-)$ & $(+)$ & $(-)^{* * * *}$ & $(+)^{*}$ & $(-)$ & $(-)$ & $(+)$ & $(-)$ & $(-)^{* * * *}$ & $(+)$ & $(-)^{* * * *}$ & $(+)$ \\
\hline
\end{tabular}

Note: Parameters signs are reported in brackets.

* Refers to $10 \%$ statistical significance.

** Refers to 5\% statistical significance.

*** Refers to $1 \%$ statistical significance.

Bus. and Pol. refer to Business and Political news, respectively.

Interestingly, the percentage of (business and political) negative news rarely exceeds $20 \%$. The highest mean values for negative business news are those for the Qatari, Saudi and UAE ones (0.056, 0.056 and 0.057 respectively; the corresponding standard deviations are $0.048,0.058$ and 0.031 ); by contrast, the highest mean values for negative political news are those for Bahrain (0.095) followed by Saudi (0.059) and UAE (0.053). It is noteworthy that the percentage of negative business news exceeds that of negative political news in the case of Oman, Qatar and UAE. However, negative political news appear to be more volatile than negative business news in all GCC countries, especially in the case of Bahrain and Oman, where they are at least three times as volatile.

As for the control variables, GDP news surprises seem to be negative for the region as a whole, with an overall index equal to - 0.733. However, this disguises cross-country differences; specifically, this variable is positive in Bahrain, Kuwait and the UAE, whereas it is negative in Oman, Qatar and Saudi Arabia.

Concerning the correlation coefficients (Table 3), it appears that stock market returns in the region are all positively correlated to one another. The highest degrees of correlations are those between the leading stock markets (Qatar, Saudi Arabia and the two UAE indexes) exceeding 0.50, whereas the Bahrain and Oman markets are less strongly correlated. A positive correlation is also found 
Table 5

Markov switching model - summary results.

\begin{tabular}{|c|c|c|c|c|c|c|c|c|c|c|c|c|}
\hline \multirow{3}{*}{$\begin{array}{l}\text { Effects from } \\
\text { Effects to }\end{array}$} & \multicolumn{2}{|c|}{ Bahrain news } & \multicolumn{2}{|c|}{ KSA news } & \multicolumn{2}{|c|}{ Kuwait news } & \multicolumn{2}{|c|}{ Oman news } & \multicolumn{2}{|c|}{ Qatar news } & \multicolumn{2}{|c|}{ UAE news } \\
\hline & Bus. & Pol. & Bus. & Pol. & Bus. & Pol. & Bus. & Pol. & Bus. & Pol. & Bus. & Pol. \\
\hline & \multicolumn{12}{|c|}{ Low regime } \\
\hline Bahrain & $(+)$ & $(-)$ & $(-)$ & $(+)$ & $(+)$ & $(+)$ & $(+)$ & $(+)$ & $(-)^{* *}$ & $(+)$ & $(-)^{* *}$ & $(-)$ \\
\hline KSA & $(+)$ & $(+)$ & $(-)^{* *}$ & $(+)$ & $(+)$ & $(+)$ & $(+)$ & $(+)$ & $(-)^{* * *}$ & $(+)$ & $(-)$ & $(-)^{*}$ \\
\hline Kuwait & $(-)$ & $(+)$ & $(-)^{* * *}$ & $(+)$ & $(-)$ & $(+)$ & $(-)$ & $(+)$ & $(-)$ & $(-)$ & $(-)^{*}$ & $(+)$ \\
\hline Oman & $(-)^{* *}$ & $(+)$ & $(-)^{* *}$ & $(+)^{* * *}$ & $(+)$ & $(-)$ & $(+)$ & $(+)$ & $(-)^{* *}$ & $(-)$ & $(-)^{* * *}$ & $(+)$ \\
\hline Qatar & $(-)$ & $(+)$ & $(-)^{*}$ & $(+)^{* *}$ & $(+)$ & $(+)$ & $(-)$ & $(+)$ & $(-)^{* * *}$ & $(+)$ & $(-)^{* * *}$ & $(+)$ \\
\hline UAE (Abu Dhabi) & $(-)$ & $(-)$ & $(-)^{*}$ & $(+)^{* * *}$ & $(-)$ & $(+)$ & $(+)$ & $(+)$ & $(-)$ & $(+)$ & $(-)$ & $(-)$ \\
\hline UAE (Dubai) & $(-)$ & $(-)$ & $(-)$ & $(+)^{*}$ & $(+)$ & $(+)$ & $(+)$ & $(+)$ & $(-)^{*}$ & $(-)$ & $(-)^{* *}$ & $(-)$ \\
\hline Effects to & \multicolumn{12}{|c|}{ High Regime } \\
\hline Bahrain & $(-)$ & $(+)$ & $(-)^{* * *}$ & $(-)$ & $(-)$ & $(-)$ & $(-)^{* *}$ & $(+)$ & $(-)^{* * *}$ & $(+)$ & $(+)$ & $(+)$ \\
\hline KSA & $(+)$ & $(-)$ & $(-)$ & $(-)$ & $(-)$ & $(-)$ & $(-)$ & $(-)$ & $(-)$ & $(-)^{*}$ & $(-)^{* * *}$ & $(+)$ \\
\hline Kuwait & $(-)^{* *}$ & $(+)$ & $(-)^{* * *}$ & $(+)^{* *}$ & $(-)$ & $(+)$ & $(-)$ & $(-)$ & $(-)^{*}$ & $(-)^{*}$ & $(-)^{* * *}$ & $(+)^{*}$ \\
\hline Oman & $(-)^{* * *}$ & $(-)$ & $(-)^{* *}$ & $(-)$ & $(+)$ & $(-)$ & $(-)$ & $(-)$ & $(-)^{* *}$ & $(-)$ & $(-)$ & $(+)$ \\
\hline Qatar & $(-)$ & $(+)$ & $(-)^{* *}$ & $(+)$ & $(-)^{* *}$ & $(+)$ & $(-)$ & $(+)$ & $(-)^{* * *}$ & $(+)$ & $(-)^{* * *}$ & $(+)$ \\
\hline UAE (Abu Dhabi) & $(-)$ & $(+)$ & $(-)^{*}$ & $(+)^{*}$ & $(-)$ & $(+)$ & $(-)$ & $(-)^{*}$ & $(-)^{* * *}$ & $(+)$ & $(-)^{* * *}$ & $(+)$ \\
\hline UAE (Dubai) & $(-)$ & $(-)$ & $(-)$ & $(-)$ & $(-)$ & $(-)$ & $(-)$ & $(+)$ & $(-)^{*}$ & $(+)$ & $(-)^{*}$ & $(+)$ \\
\hline
\end{tabular}

Note: Parameters signs are reported in brackets.

* Refers to $10 \%$ statistical significance.

** Refers to $5 \%$ statistical significance.

*** Refers to $1 \%$ statistical significance.

Bus. and Pol. refer to Business and Political news, respectively.
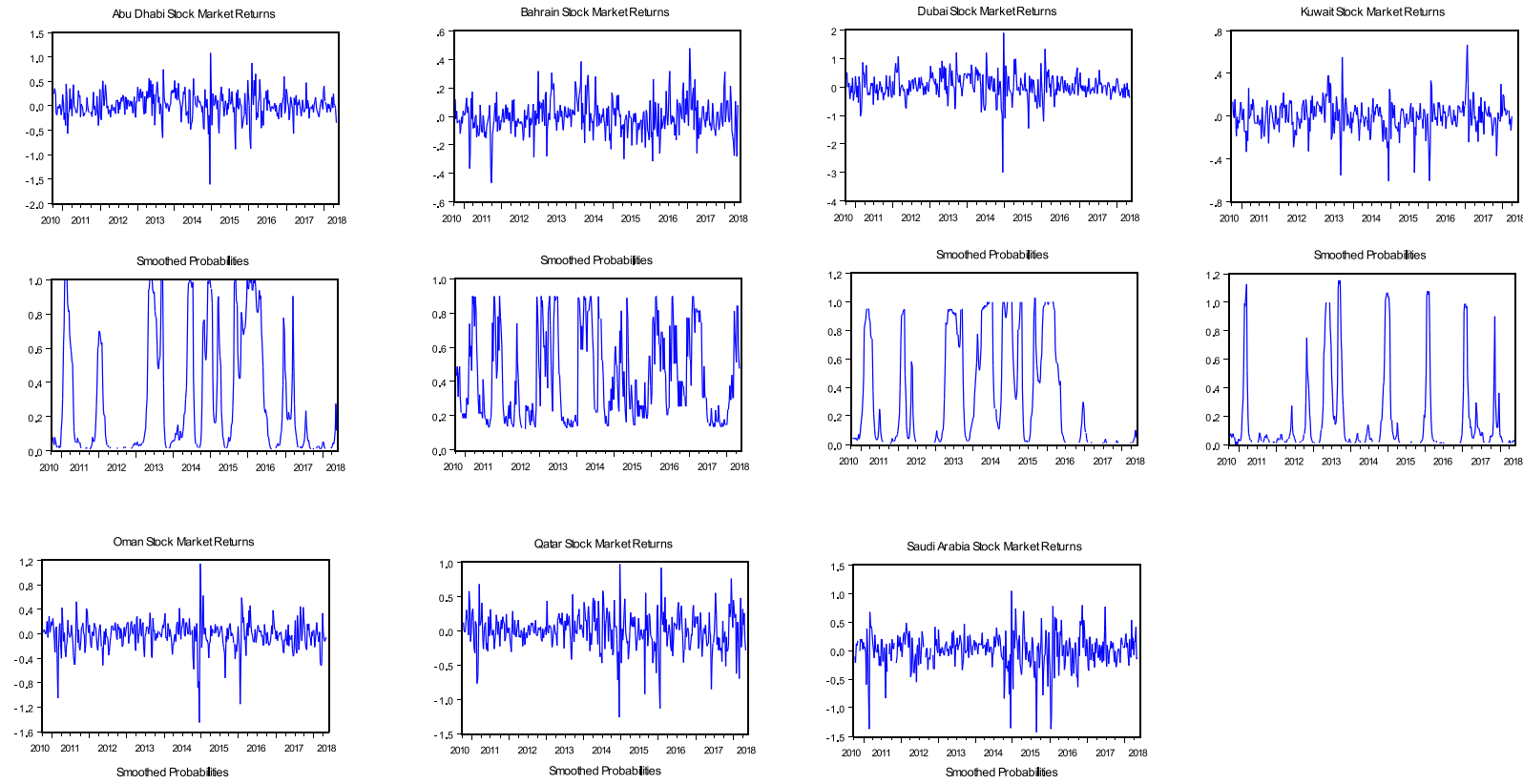

Smooned Probabilifes
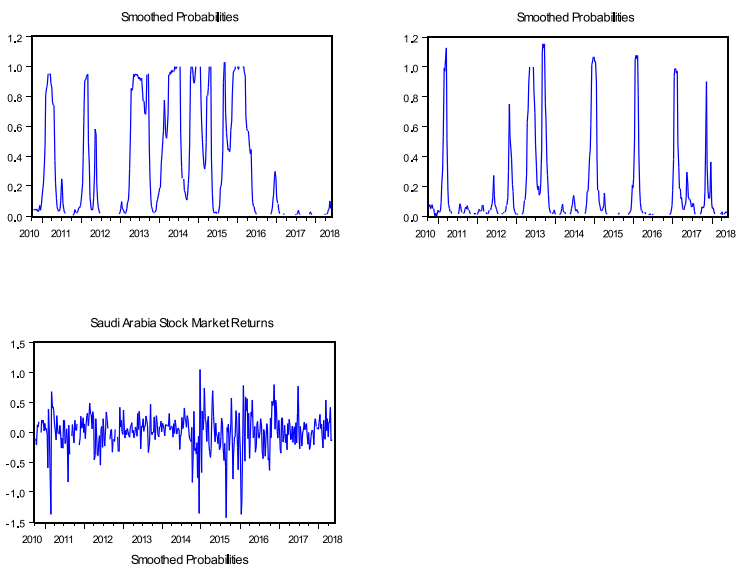
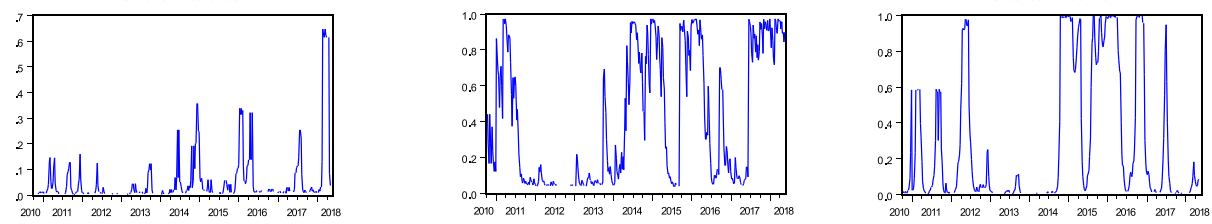

Fig. 4. Stock market returns and smoothed probabilities. Note: Stock returns in country $i$ are the weekly returns of the stock market index for country $i$ at time $t$. Smoothed probabilities refer to the probability to be in the high regime for country $i$ at time $t$. 
across the region for both business news and political news, especially for the former. Negative business news correlations between Qatar, Saudi Arabia and the UAE all exceed 0.355, with the highest degree of correlation being that between Qatar and UAE (0.477). On the other hand, the highest degree of correlation for negative political news occurs between Bahrain and Oman (0.436). All other correlations, albeit positive, suggest a low degree of integration with values in the range 0.029-0.349.

\subsection{Empirical results}

A summary of the estimation results for the linear and Markov-switching models, respectively, is presented in Tables 4 and $5 .{ }^{4}$ Overall, the results indicate that the latter specification captures satisfactorily the shifts in mean/variance for all series considered. We select the optimal lag length of the mean equation using the Schwarz information criterion. In order to test the adequacy of the models, Ljung-Box portmanteau tests were performed on the standardised and standardised squared residuals. The results for the latter show the inability of the linear model to capture the time-varying nature of the second moment. The non-linear specification chosen aims to address this issue as well.

The linear (benchmark) estimates suggest that negative business news about the largest markets in the region (Qatar, Saudi Arabia and UAE) have a significant and negative cross-border effect on all GCC countries. Domestic negative business news affect significantly the larger stock markets, but not the smaller ones (Bahrain, Kuwait and Oman). The latter seem to be more sensitive to negative news concerning the larger markets rather than to domestic ones. On the contrary, negative business news concerning the smaller markets seem to influence only the peripheral markets but not the leading ones. As for the impact of political news, the results provide very little evidence of any statistically significant effects. The only noticeable exception is given by Saudi Arabia, whose negative political news affect positively all markets except the Qatari one.

Next we discuss the Markov-switching estimation results. It is clear that the non-linear specification fits the data better. The smoothed probabilities (Fig. 4) show that two regimes (low and high) can be clearly identified and the second moment governs the switching between the two in all stock markets, though to a less extent in the case of Oman. The transition probabilities indicate that the low volatilitiy regime is characterised by higher persistence compared to the high volatility one $\left(p_{\text {high,high }}<p_{\text {low,low }}\right)$.

As for the casual linkages between the variables in the system, it appears that the Abu Dhabi stock market is affected by negative business news from Saudi Arabia, Qatar and UAE in the high volatility regime, whereas it is only affected by negative news from Saudi Arabia in the low volatility regime. Negative political news do not seem to affect this market except for those from Saudi Arabia. Bahrain stock returns are affected by business news in Qatar and UAE in the low regime, whereas they are strongly affected by Qatari and Saudi business news in the high regime with point estimates equal to -0.772 and -0.970 respectively. Domestic business news do not seem to have any effect on Bahrain stock returns. The same applies to political news.

The Dubai stock market is affected by Qatari and domestic business news in both regimes, with point estimates in the high regime equal to -2.211 and -3.052 respectively, these being three times as big as the corresponding values in the low regime, -0.639 and -1.021 respectively. The Dubai stock market only seems to be affected by Saudi political news, although marginally. The Qatar stock market is affected by domestic, Saudi and UAE news in both regimes as well as by Kuwait news in the high regime. The size of the impact is not very different across regimes except for the UAE in the more volatile regime. News from Bahrain and Oman do not have any impact. Only Saudi political news seem to affect the Qatari stock markets in periods of low volatility.

The Kuwait stock market is affected by Saudi $(-0.257)$ and UAE $(-0.358)$ news in the low regime, whereas in the high regime it is affected by Bahrain ( -0.241$)$ news, and particularly strongly by Saudi, Qatari and UAE business news with large point estimates equal to $-0.982,-0.985$ and -0.476 respectively. The Kuwait market is affected by political news originating from Saudi Arabia and Qatar but only in the high regime. The Oman stock market is affected by negative business news from Bahrain ( -0.230$)$, Saudi Arabia $(-0.972)$, Qatar $(-0.451)$ and the UAE $(-0.164)$ in the low regime. The same pattern is observed in the high regime. Oman seems to be affected only by Saudi negative political news in the low regime.

Saudi Arabia is greatly affected by domestic (-0.998) and Qatari ( -0.397$)$ business news in the low volatility regime; instead in the high regime it is strongly influenced by Qatari (-0.982) and UAE (-4.081) business news. Political news originating in UAE (0.196) affect Saudi Arabia in the low volatility regime, whilst Qatari political news have a negative effect $(-0.952)$ in the high regime.

In brief, business news are clearly a more important driver of stock returns than political news. While domestic business news generally seem to play a significant role, this is not the case for political news. The three largest stock markets have a leading role also in terms of the importance given by investors to business news concerning these countries, which affect the smaller markets. The results for political news are instead mixed and no clear pattern emerges. Further, the control variables are statistically significant for all leading markets, the estimated coefficients indicating a negative VIX and interest rate effect, whereas domestic macro news surprises have a significant (often positive) effect only in a few cases. Oil prices do not seem to have a significant effect when the linear model is estimated; however, they are mostly positive and significant when the Markov-switching specification is adopted. ${ }^{5}$

\footnotetext{
${ }^{4}$ The complete set of estimation results with the associated robust $p$-values and likelihood function values are reported in the Appendix, Tables A.1-A.11.

${ }^{5}$ Trade could be a significant factor driving the stock markets of GCC emerging markets. However, this hypothesis cannot be tested directly using our framework, given the low frequency of the data on trade.
} 


\section{Conclusions}

This paper uses both linear and non-linear specifications to analyses spillovers between business and political news and stock returns for a group of emerging countries belonging to the Gulf Cooperation Council (GCC) over the period October 2010-May 2018. It makes several contributions to the existing literature: (i) it considers news in the form of newspaper headlines, that provide an interpretation of business and political releases driving agents' investment decisions; (ii) it adopts an econometric framework shedding light on the potential non-linear dynamic linkages between stock returns and their possible determinants; (iii) it focuses on the GCC countries providing extensive new evidence; (iv) it controls for domestic monetary policy and other economic and financial shocks. The non-linear specification appears to be more data congruent than the benchmark linear model. On the whole, the results suggest the existence of significant linkages between negative business news and stock returns. Importantly, business news from the larger economies have not only domestic but also cross-border negative effects. By contrast, there is weak evidence of causality running from political news to stock returns. A possible explanation is that political news by their own nature are not as easy to classify as business news. Further research could apply more sophisticated criteria to categorise them on the basis of more extensive textual analysis.

\section{Appendix A}

Table A.1

Linear results for the Bahrain \& Kingdom of Saudi Arabia stock markets.

\begin{tabular}{|c|c|c|c|c|c|c|c|c|c|c|c|c|}
\hline \multicolumn{13}{|c|}{ Bahrain stock market } \\
\hline \multirow{2}{*}{$\begin{array}{l}\text { News from - > } \\
\text { Variable }\end{array}$} & \multicolumn{2}{|l|}{ Bahrain } & \multicolumn{2}{|l|}{ KSA } & \multicolumn{2}{|l|}{ Kuwait } & \multicolumn{2}{|l|}{ Oman } & \multicolumn{2}{|l|}{ Qatar } & \multicolumn{2}{|l|}{ UAE } \\
\hline & Coeff. & Prob. & Coeff. & Prob. & Coeff. & Prob. & Coeff. & Prob. & Coeff. & Prob. & Coeff. & Prob. \\
\hline$\mu$ & 0.099 & 0.064 & 0.100 & 0.001 & 0.102 & 0.007 & 0.094 & 0.166 & 0.126 & 0.001 & 0.102 & 0.003 \\
\hline Business news & 0.002 & 0.448 & -0.008 & 0.024 & -0.013 & 0.049 & -0.007 & 0.528 & 0.004 & 0.407 & -0.012 & 0.055 \\
\hline Political news & 0.000 & 0.931 & 0.003 & 0.038 & 0.002 & 0.308 & 0.003 & 0.314 & 0.001 & 0.552 & -0.001 & 0.671 \\
\hline $\mathrm{r}_{t-1}$ & -0.078 & 0.512 & -0.039 & 0.572 & -0.025 & 0.748 & -0.134 & 0.400 & -0.072 & 0.361 & -0.080 & 0.275 \\
\hline $\mathrm{r}_{t-2}$ & -0.015 & 0.935 & -0.095 & 0.331 & -0.155 & 0.182 & -0.054 & 0.819 & -0.109 & 0.360 & -0.009 & 0.937 \\
\hline Oil & -0.002 & 0.333 & -0.001 & 0.467 & -0.002 & 0.223 & -0.001 & 0.735 & 0.000 & 0.805 & 0.000 & 0.778 \\
\hline VIX & -0.007 & 0.000 & -0.003 & 0.011 & -0.003 & 0.007 & -0.005 & 0.022 & -0.004 & 0.004 & -0.004 & 0.002 \\
\hline Bah. surprises & 0.002 & 0.014 & 0.000 & 0.718 & 0.001 & 0.177 & 0.001 & 0.273 & 0.000 & 0.859 & 0.000 & 0.722 \\
\hline Bah. interest & -0.003 & 0.106 & 0.001 & 0.493 & -0.001 & 0.261 & -0.001 & 0.446 & -0.001 & 0.247 & 0.001 & 0.576 \\
\hline$\sigma$ & 0.098 & 0.000 & 0.095 & 0.000 & 0.101 & 0.000 & 0.094 & 0.000 & 0.096 & 0.000 & 0.095 & 0.000 \\
\hline $\mathrm{Q}_{(4)}$ & 1.565 & & 3.443 & & 4.098 & & 2.112 & & 3.086 & & 3.331 & \\
\hline $\mathrm{Q}_{(4)}^{2}$ & 13.567 & & 14.543 & & 13.976 & & 14.012 & & 14.784 & & 13.998 & \\
\hline Log-lik & 400.67 & & 412.65 & & 442.02 & & 315.12 & & 426.07 & & 371.12 & \\
\hline \multicolumn{13}{|c|}{ KSA stock market } \\
\hline \multirow{2}{*}{$\begin{array}{l}\text { News from - > } \\
\text { Variable }\end{array}$} & \multicolumn{2}{|l|}{ Bahrain } & \multicolumn{2}{|l|}{ KSA } & \multicolumn{2}{|l|}{ Kuwait } & \multicolumn{2}{|l|}{ Oman } & \multicolumn{2}{|l|}{ Qatar } & \multicolumn{2}{|l|}{ UAE } \\
\hline & Coeff. & Prob. & Coeff. & Prob. & Coeff. & Prob. & Coeff. & Prob. & Coeff. & Prob. & Coeff. & Prob. \\
\hline$\mu$ & 0.129 & 0.127 & 0.043 & 0.325 & 0.010 & 0.890 & -0.125 & 0.277 & -0.043 & 0.488 & 0.005 & 0.913 \\
\hline Business news & 0.013 & 0.161 & -0.064 & 0.023 & 0.019 & 0.340 & 0.024 & 0.177 & -0.008 & 0.451 & -0.036 & 0.004 \\
\hline Political news & -0.006 & 0.273 & 0.027 & 0.076 & -0.009 & 0.259 & -0.001 & 0.939 & -0.006 & 0.201 & 0.000 & 0.993 \\
\hline $\mathbf{r}_{t-1}$ & 0.120 & 0.338 & 0.007 & 0.925 & 0.282 & 0.014 & -0.007 & 0.976 & 0.135 & 0.192 & 0.066 & 0.367 \\
\hline $\mathrm{r}_{t-2}$ & -0.285 & 0.070 & -0.092 & 0.368 & -0.102 & 0.479 & 0.043 & 0.849 & 0.054 & 0.699 & -0.180 & 0.069 \\
\hline Oil & 0.002 & 0.683 & 0.003 & 0.240 & 0.006 & 0.145 & 0.009 & 0.113 & 0.006 & 0.101 & 0.003 & 0.358 \\
\hline VIX & -0.007 & 0.226 & -0.001 & 0.657 & 0.000 & 0.987 & 0.006 & 0.448 & 0.010 & 0.030 & 0.001 & 0.854 \\
\hline KSA surprises & -0.001 & 0.626 & 0.001 & 0.355 & 0.000 & 0.829 & 0.008 & 0.023 & 0.003 & 0.081 & 0.002 & 0.108 \\
\hline KSA interest & 0.002 & 0.321 & -0.004 & 0.549 & -0.021 & 0.112 & -0.007 & 0.107 & -0.012 & 0.099 & -0.009 & 0.108 \\
\hline$\sigma$ & 0.151 & 0.000 & 0.152 & 0.000 & 0.153 & 0.000 & 0.155 & 0.000 & 0.154 & 0.000 & 0.151 & 0.000 \\
\hline $\mathrm{Q}_{(4)}$ & 2.065 & & 3.009 & & 4.221 & & 3.003 & & 2.995 & & 2.885 & \\
\hline $\mathrm{Q}_{(4)}^{2}$ & 12.012 & & 14.231 & & 13.065 & & 13.943 & & 14.067 & & 13.223 & \\
\hline Log-lik & 426.25 & & 500.47 & & 386.36 & & 340.19 & & 426.71 & & 440.21 & \\
\hline
\end{tabular}

Note: Autocorrelation and heteroscedasticity-consistent $p$-values (Prob.) are reported. $\mathbf{Q}_{(4)}$ and $\mathrm{Q}_{(4)}^{2}$ are the Ljung-Box test (1978) of significance of autocorrelations of four lags in the standardized and standardized squared residuals, respectively. 
Table A.2

Linear results for the Kuwait \& Oman stock markets.

\begin{tabular}{|c|c|c|c|c|c|c|c|c|c|c|c|c|}
\hline \multicolumn{13}{|c|}{ Kuwait stock market } \\
\hline \multirow{2}{*}{$\begin{array}{l}\text { News from - > } \\
\text { Variable }\end{array}$} & \multicolumn{2}{|l|}{ Bahrain } & \multicolumn{2}{|l|}{ KSA } & \multicolumn{2}{|l|}{ Kuwait } & \multicolumn{2}{|l|}{ Oman } & \multicolumn{2}{|l|}{ Qatar } & \multicolumn{2}{|l|}{ UAE } \\
\hline & Coeff. & Prob. & Coeff. & Prob. & Coeff. & Prob. & Coeff. & Prob. & Coeff. & Prob. & Coeff. & Prob. \\
\hline$\mu$ & 0.087 & 0.261 & 0.088 & 0.021 & 0.001 & 0.984 & 0.094 & 0.265 & 0.087 & 0.064 & 0.093 & 0.020 \\
\hline Business news & -0.002 & 0.734 & -0.022 & 0.000 & 0.004 & 0.305 & -0.039 & 0.002 & -0.006 & 0.353 & -0.021 & 0.001 \\
\hline Political news & -0.002 & 0.380 & 0.004 & 0.041 & 0.000 & 0.946 & 0.002 & 0.505 & -0.002 & 0.452 & 0.000 & 0.840 \\
\hline $\mathrm{r}_{t-1}$ & -0.043 & 0.695 & -0.036 & 0.527 & -0.018 & 0.815 & -0.028 & 0.808 & -0.023 & 0.713 & 0.002 & 0.969 \\
\hline $\mathbf{r}_{t-2}$ & 0.039 & 0.796 & -0.006 & 0.947 & -0.297 & 0.008 & -0.117 & 0.512 & 0.019 & 0.832 & -0.052 & 0.532 \\
\hline Oil & 0.003 & 0.329 & 0.000 & 0.894 & 0.004 & 0.066 & 0.007 & 0.072 & 0.002 & 0.279 & 0.004 & 0.053 \\
\hline VIX & -0.002 & 0.376 & -0.002 & 0.115 & 0.002 & 0.345 & -0.002 & 0.517 & -0.003 & 0.118 & -0.004 & 0.010 \\
\hline Kuw. surprises & 0.000 & 0.544 & 0.000 & 0.381 & -0.001 & 0.249 & 0.001 & 0.269 & 0.000 & 0.501 & 0.000 & 0.452 \\
\hline Kuw. interest & 0.001 & 0.841 & -0.001 & 0.728 & 0.005 & 0.038 & 0.003 & 0.418 & 0.001 & 0.923 & 0.001 & 0.586 \\
\hline$\sigma$ & 0.132 & 0.000 & 0.131 & 0.000 & 0.137 & 0.000 & 0.135 & 0.000 & 0.141 & 0.000 & 0.036 & 0.000 \\
\hline $\mathrm{Q}_{(4)}$ & 2.996 & & 2.553 & & 3.006 & & 3.109 & & 2.786 & & 3.001 & \\
\hline $\mathrm{Q}_{(4)}^{2}$ & 11.098 & & 12.987 & & 12.453 & & 13.112 & & 11.012 & & 12.187 & \\
\hline Log-lik & 467.95 & & 416.32 & & 496.78 & & 405.52 & & 502.01 & & 478.55 & \\
\hline \multicolumn{13}{|c|}{ Oman stock market } \\
\hline \multirow{2}{*}{$\begin{array}{l}\text { News from - > } \\
\text { Variable }\end{array}$} & \multicolumn{2}{|l|}{ Bahrain } & \multicolumn{2}{|l|}{ KSA } & \multicolumn{2}{|l|}{ Kuwait } & \multicolumn{2}{|l|}{ Oman } & \multicolumn{2}{|l|}{ Qatar } & \multicolumn{2}{|l|}{ UAE } \\
\hline & Coeff. & Prob. & Coeff. & Prob. & Coeff. & Prob. & Coeff. & Prob. & Coeff. & Prob. & Coeff. & Prob. \\
\hline$\mu$ & 0.006 & 0.764 & 0.001 & 0.905 & 0.009 & 0.541 & -0.045 & 0.123 & 0.011 & 0.407 & -0.007 & 0.567 \\
\hline Business news & -0.004 & 0.053 & -0.011 & 0.000 & -0.004 & 0.225 & 0.002 & 0.770 & -0.006 & 0.045 & -0.014 & 0.000 \\
\hline Political news & 0.000 & 0.743 & 0.002 & 0.050 & 0.001 & 0.390 & -0.002 & 0.394 & 0.002 & 0.265 & 0.000 & 0.993 \\
\hline $\mathrm{r}_{t-1}$ & 0.010 & 0.760 & 0.006 & 0.809 & 0.031 & 0.293 & 0.118 & 0.039 & 0.016 & 0.564 & 0.027 & 0.345 \\
\hline $\mathrm{r}_{t-2}$ & -0.014 & 0.746 & -0.011 & 0.746 & 0.027 & 0.528 & -0.111 & 0.036 & 0.002 & 0.963 & -0.051 & 0.210 \\
\hline Oil & -0.152 & 0.014 & -0.109 & 0.007 & -0.250 & 0.000 & -0.353 & 0.001 & -0.138 & 0.003 & -0.138 & 0.003 \\
\hline VIX & 1.154 & 0.000 & 1.114 & 0.000 & 1.191 & 0.000 & 1.351 & 0.000 & 1.118 & 0.000 & 1.163 & 0.000 \\
\hline Oman surprises & 0.001 & 0.368 & 0.000 & 0.649 & 0.001 & 0.248 & 0.000 & 0.830 & 0.001 & 0.477 & 0.000 & 0.570 \\
\hline Oman interest & 0.001 & 0.597 & 0.001 & 0.555 & 0.001 & 0.912 & 0.002 & 0.318 & 0.001 & 0.913 & 0.001 & 0.736 \\
\hline$\sigma$ & 0.148 & 0.000 & 0.145 & 0.000 & 0.151 & 0.000 & 0.144 & 0.000 & 0.147 & 0.000 & 0.152 & 0.000 \\
\hline $\mathrm{Q}_{(4)}$ & 2.007 & & 2.552 & & 2.445 & & 2.652 & & 2.772 & & 2.441 & \\
\hline$Q_{(4)}^{2}$ & 9.994 & & 10.007 & & 11.567 & & 12.987 & & 12.223 & & 13.032 & \\
\hline Log-lik & 504.09 & & 512.98 & & 505.05 & & 432.11 & & 459.01 & & 448.13 & \\
\hline
\end{tabular}

Note: See notes Table A.1.

Table A.3

Linear results for the Qatar \& UAE (Abu Dhabi) stock markets.

\begin{tabular}{|c|c|c|c|c|c|c|c|c|c|c|c|c|}
\hline \multicolumn{13}{|c|}{ Qatar Stock Market } \\
\hline \multirow{2}{*}{$\begin{array}{l}\text { News from - > } \\
\text { Variable }\end{array}$} & \multicolumn{2}{|l|}{ Bahrain } & \multicolumn{2}{|l|}{ KSA } & \multicolumn{2}{|l|}{ Kuwait } & \multicolumn{2}{|l|}{ Oman } & \multicolumn{2}{|l|}{ Qatar } & \multicolumn{2}{|l|}{ UAE } \\
\hline & Coeff. & Prob. & Coeff. & Prob. & Coeff. & Prob. & Coeff. & Prob. & Coeff. & Prob. & Coeff. & Prob. \\
\hline$\mu$ & 0.063 & 0.313 & 0.058 & 0.179 & 0.066 & 0.157 & 0.027 & 0.741 & 0.116 & 0.040 & 0.053 & 0.245 \\
\hline Business news & -0.007 & 0.457 & -0.032 & 0.000 & 0.006 & 0.649 & -0.001 & 0.958 & -0.001 & 0.885 & -0.034 & 0.005 \\
\hline Political news & 0.001 & 0.870 & 0.002 & 0.601 & -0.001 & 0.831 & -0.003 & 0.611 & 0.006 & 0.410 & 0.000 & 0.892 \\
\hline $\mathbf{r}_{t-1}$ & 0.133 & 0.133 & 0.055 & 0.290 & 0.033 & 0.538 & 0.162 & 0.073 & 0.054 & 0.404 & 0.051 & 0.371 \\
\hline $\mathrm{r}_{t-2}$ & -0.180 & 0.215 & -0.114 & 0.131 & -0.023 & 0.784 & -0.120 & 0.444 & -0.226 & 0.022 & -0.107 & 0.217 \\
\hline Oil & -0.010 & 0.002 & -0.003 & 0.126 & -0.001 & 0.639 & -0.003 & 0.352 & -0.002 & 0.544 & -0.003 & 0.188 \\
\hline VIX & -0.005 & 0.210 & -0.002 & 0.350 & -0.006 & 0.023 & -0.005 & 0.289 & -0.004 & 0.236 & -0.006 & 0.053 \\
\hline Qatar surprises & -0.002 & 0.126 & -0.001 & 0.538 & -0.001 & 0.352 & -0.001 & 0.615 & 0.000 & 0.798 & -0.001 & 0.284 \\
\hline Qatar interest & 0.002 & 0.517 & 0.001 & 0.823 & 0.001 & 0.565 & 0.004 & 0.254 & 0.003 & 0.314 & 0.002 & 0.392 \\
\hline$\sigma$ & 0.155 & 0.000 & 0.153 & 0.000 & 0.162 & 0.000 & 0.149 & 0.000 & 0.158 & 0.000 & 0.199 & 0.000 \\
\hline $\mathrm{Q}_{(4)}$ & 3.556 & & 4.098 & & 4.112 & & 4.336 & & 4.068 & & 3.995 & \\
\hline $\mathrm{Q}_{(4)}^{2}$ & 11.098 & & 12.345 & & 11.954 & & 10.886 & & 10.739 & & 12.976 & \\
\hline Log-lik & 438.48 & & 386.56 & & 397.11 & & 290.49 & & 362.64 & & 445.02 & \\
\hline
\end{tabular}


Table A.3 (continued)

UAE (Abu Dhabi) stock market

\begin{tabular}{|c|c|c|c|c|c|c|c|c|c|c|c|c|}
\hline \multirow{2}{*}{$\begin{array}{l}\text { News from - > } \\
\text { Variable }\end{array}$} & \multicolumn{2}{|l|}{ Bahrain } & \multicolumn{2}{|l|}{ KSA } & \multicolumn{2}{|l|}{ Kuwait } & \multicolumn{2}{|l|}{ Oman } & \multicolumn{2}{|l|}{ Qatar } & \multicolumn{2}{|l|}{ UAE } \\
\hline & Coeff. & Prob. & Coeff. & Prob. & Coeff. & Prob. & Coeff. & Prob. & Coeff. & Prob. & Coeff. & Prob. \\
\hline$\mu$ & 0.051 & 0.390 & 0.075 & 0.071 & 0.106 & 0.040 & -0.089 & 0.166 & 0.016 & 0.719 & -0.011 & 0.812 \\
\hline Business news & -0.005 & 0.596 & -0.060 & 0.000 & -0.013 & 0.501 & 0.019 & 0.398 & -0.044 & 0.000 & 0.002 & 0.844 \\
\hline Political news & 0.000 & 0.963 & 0.005 & 0.232 & -0.002 & 0.760 & -0.003 & 0.669 & 0.008 & 0.069 & 0.003 & 0.475 \\
\hline $\mathrm{r}_{t-1}$ & 0.183 & 0.041 & -0.050 & 0.463 & -0.020 & 0.810 & -0.083 & 0.470 & -0.093 & 0.201 & -0.062 & 0.411 \\
\hline $\mathrm{r}_{t-2}$ & -0.347 & 0.013 & 0.106 & 0.230 & 0.164 & 0.130 & 0.008 & 0.958 & 0.281 & 0.004 & 0.035 & 0.746 \\
\hline Oil & -0.007 & 0.123 & -0.005 & 0.181 & -0.002 & 0.725 & -0.003 & 0.581 & -0.003 & 0.369 & 0.001 & 0.952 \\
\hline VIX & -0.004 & 0.383 & -0.002 & 0.639 & -0.007 & 0.103 & 0.002 & 0.684 & 0.001 & 0.788 & -0.003 & 0.446 \\
\hline UAE surprises & 0.002 & 0.456 & 0.001 & 0.974 & -0.002 & 0.523 & 0.007 & 0.053 & 0.001 & 0.928 & 0.002 & 0.583 \\
\hline UAE interest & -0.007 & 0.032 & -0.009 & 0.001 & -0.008 & 0.004 & -0.001 & 0.781 & -0.005 & 0.026 & -0.004 & 0.096 \\
\hline$\sigma$ & 0.271 & 0,000 & 0.266 & 0.000 & 0.283 & 0.000 & 0.279 & 0.000 & 0.291 & 0.000 & 0.288 & 0.000 \\
\hline$Q_{(4)}$ & 4.885 & & 4.563 & & 4.442 & & 4.551 & & 4.138 & & 4.342 & \\
\hline$Q_{(4)}^{2}$ & 10.453 & & 11.876 & & 9.987 & & 10.895 & & 12.776 & & 12.098 & \\
\hline Log-lik & 420.54 & & 384.39 & & 500.88 & & 276.34 & & 462.03 & & 470.88 & \\
\hline
\end{tabular}

Note: See notes Table A.1.

Table A.4

Linear results for the UAE (Dubai) stock market.

\begin{tabular}{|c|c|c|c|c|c|c|c|c|c|c|c|c|}
\hline \multicolumn{13}{|c|}{ UAE (Dubai) Stock Market } \\
\hline \multirow{2}{*}{$\begin{array}{l}\text { News from - > } \\
\text { Variable }\end{array}$} & \multicolumn{2}{|l|}{ Bahrain } & \multicolumn{2}{|l|}{ KSA } & \multicolumn{2}{|l|}{ Kuwait } & \multicolumn{2}{|l|}{ Oman } & \multicolumn{2}{|l|}{ Qatar } & \multicolumn{2}{|l|}{ UAE } \\
\hline & Coeff. & Prob. & Coeff. & Prob. & Coeff. & Prob. & Coeff. & Prob. & Coeff. & Prob. & Coeff. & Prob. \\
\hline$\mu$ & 0.123 & 0.137 & 0.287 & 0.001 & 0.073 & 0.353 & 0.091 & 0.345 & 0.065 & 0.413 & 0.059 & 0.459 \\
\hline Business news & 0.001 & 0.948 & -0.111 & 0.782 & -0.031 & 0.401 & -0.027 & 0.387 & -0.113 & 0.001 & -0.141 & 0.005 \\
\hline Political news & -0.005 & 0.372 & 0.481 & 0.081 & 0.011 & 0.336 & 0.006 & 0.616 & -0.006 & 0.541 & 0.012 & 0.371 \\
\hline $\mathrm{r}_{t-1}$ & -0.136 & 0.008 & 0.203 & 0.001 & -0.048 & 0.361 & -0.045 & 0.469 & -0.091 & 0.077 & -0.061 & 0.219 \\
\hline $\mathrm{r}_{t-2}$ & 0.188 & 0.019 & -0.091 & 0.193 & 0.152 & 0.059 & 0.157 & 0.083 & 0.159 & 0.043 & 0.157 & 0.048 \\
\hline Oil & 0.009 & 0.191 & 0.012 & 0.079 & 0.006 & 0.339 & 0.001 & 0.834 & 0.009 & 0.178 & 0.002 & 0.732 \\
\hline VIX & -0.001 & 0.846 & -0.017 & 0.001 & -0.004 & 0.511 & -0.008 & 0.265 & -0.001 & 0.333 & -0.001 & 0.807 \\
\hline UAE surprises & 0.001 & 0.775 & -0.073 & 0.002 & 0.005 & 0.352 & 0.001 & 0.992 & 0.004 & 0.369 & 0.002 & 0.693 \\
\hline UAE interest & -0.006 & 0.141 & -0.005 & 0.050 & -0.009 & 0.029 & -0.005 & 0.247 & -0.009 & 0.024 & -0.009 & 0.021 \\
\hline$\sigma$ & 0.421 & 0.000 & 0.427 & 0.000 & 0.410 & 0.000 & 0.424 & 0.000 & 0.412 & 0.000 & 0.409 & 0.000 \\
\hline $\mathrm{Q}_{(4)}$ & 1.754 & & 3.667 & & 2.113 & & 1.532 & & 1.978 & & 1.963 & \\
\hline $\mathrm{Q}_{(4)}^{2}$ & 6.445 & & 7.554 & & 8.112 & & 8.445 & & 9.223 & & 8.554 & \\
\hline Log-lik & 435.55 & & 399.03 & & 421.97 & & 470.51 & & 432.77 & & 446.44 & \\
\hline
\end{tabular}

Note: See notes Table A.1.

Table A.5

Markov switching results - Bahrain stock market.

\begin{tabular}{|c|c|c|c|c|c|c|c|c|c|c|c|c|}
\hline \multirow{2}{*}{$\begin{array}{l}\text { News from - > } \\
\text { Variable }\end{array}$} & \multicolumn{2}{|l|}{ Bahrain } & \multicolumn{2}{|l|}{ KSA } & \multicolumn{2}{|l|}{ Kuwait } & \multicolumn{2}{|l|}{ Oman } & \multicolumn{2}{|l|}{ Qatar } & \multicolumn{2}{|l|}{ UAE } \\
\hline & Coeff. & Prob. & Coeff. & Prob. & Coeff. & Prob. & Coeff. & Prob. & Coeff. & Prob. & Coeff. & Prob. \\
\hline \multicolumn{13}{|l|}{ Regime low } \\
\hline$\mu^{l}$ & 0.037 & 0.052 & 0.057 & 0.003 & 0.064 & 0.006 & 0.024 & 0.301 & 0.056 & 0.000 & 0.067 & 0.003 \\
\hline Business news & 0.071 & 0.181 & -0.088 & 0.290 & 0.003 & 0.694 & 0.043 & 0.456 & -0.136 & 0.025 & -0.481 & 0.041 \\
\hline Political news & -0.014 & 0.662 & 0.015 & 0.618 & 0.158 & 0.102 & 0.032 & 0.897 & 0.033 & 0.465 & -0.047 & 0.339 \\
\hline$\sigma^{l}$ & 0.033 & 0.000 & 0.027 & 0.000 & 0.028 & 0.000 & 0.031 & 0.000 & 0.051 & 0.000 & 0.032 & 0.000 \\
\hline \multicolumn{13}{|l|}{ Regime high } \\
\hline$\mu^{h}$ & 0.089 & 0.003 & 0.333 & 0.000 & 0.106 & 0.002 & 0.081 & 0.006 & 0.132 & 0.000 & 0.079 & 0.008 \\
\hline Business news & -0.070 & 0.320 & -0.970 & 0.001 & -0.809 & 0.115 & -0.636 & 0.045 & -0.772 & 0.007 & 0.204 & 0.714 \\
\hline Political news & 0.011 & 0.615 & -0.004 & 0.911 & -0.097 & 0.558 & 0.071 & 0.498 & 0.033 & 0.103 & -0.021 & 0.343 \\
\hline$\sigma^{h}$ & 0.036 & 0.000 & -0.038 & 0.931 & 0.039 & 0.000 & 0.037 & 0.000 & 0.062 & 0.000 & 0.038 & 0.000 \\
\hline
\end{tabular}


Table A.5 (continued)

\begin{tabular}{|c|c|c|c|c|c|c|c|c|c|c|c|c|}
\hline \multirow{2}{*}{$\begin{array}{l}\text { News from - > } \\
\text { Variable }\end{array}$} & \multicolumn{2}{|l|}{ Bahrain } & \multicolumn{2}{|l|}{ KSA } & \multicolumn{2}{|l|}{ Kuwait } & \multicolumn{2}{|l|}{ Oman } & \multicolumn{2}{|l|}{ Qatar } & \multicolumn{2}{|l|}{ UAE } \\
\hline & Coeff. & Prob. & Coeff. & Prob. & Coeff. & Prob. & Coeff. & Prob. & Coeff. & Prob. & Coeff. & Prob. \\
\hline \multicolumn{13}{|l|}{ Control variables } \\
\hline $\mathrm{r}_{t-1}$ & 0.261 & 0.000 & 0.162 & 0.000 & 0.244 & 0.000 & 0.272 & 0.000 & 0.228 & 0.000 & & \\
\hline $\mathrm{r}_{t-2}$ & -0.083 & 0.129 & -0.047 & 0.327 & -0.012 & 0.787 & -0.087 & 0.144 & -0.085 & 0.342 & & \\
\hline Oil & 0.070 & 0.000 & 0.005 & 0.512 & 0.006 & 0.344 & 0.074 & 0.000 & 0.027 & 0.000 & 0.010 & 0.000 \\
\hline VIX & 0.054 & 0.000 & -0.023 & 0.018 & -0.019 & 0.020 & 0.052 & 0.000 & -0.071 & 0.000 & 0.049 & 0.025 \\
\hline Bah. surprises & -0.062 & 0.000 & -0.028 & 0.000 & -0.028 & 0.000 & -0.063 & 0.000 & -0.074 & 0.000 & -0.072 & 0.000 \\
\hline Bah. interest & -0.010 & 0.317 & -0.062 & 0.000 & -0.057 & 0.000 & -0.013 & 0.207 & -0.080 & 0.000 & -0.007 & 0.406 \\
\hline \multicolumn{13}{|c|}{ Transition matrix parameters } \\
\hline$p_{\text {low,low }}$ & 0.922 & 0.000 & 0.911 & 0.000 & 0.931 & 0.000 & 0.909 & 0.000 & 0.943 & 0.000 & 0.903 & 0.000 \\
\hline$p_{\text {high,high }}$ & 0.877 & 0.000 & 0.898 & 0.000 & 0.887 & 0.000 & 0.899 & 0.000 & 0.901 & 0.000 & 0.893 & 0.000 \\
\hline $\mathrm{Q}_{(4)}$ & 0.488 & & 0.228 & & 0.233 & & 0.523 & & 0.144 & & 0.377 & \\
\hline $\mathrm{Q}_{(4)}^{2}$ & 4.009 & & 4.552 & & 3.997 & & 3.889 & & 3.657 & & 4.453 & \\
\hline Log-lik & 427.510 & & 475.452 & & 443.491 & & 491.383 & & 398.982 & & 416.141 & \\
\hline
\end{tabular}

Note: Autocorrelation and heteroscedasticity-consistent $p$-values (Prob.) are calculated by means of maximum likelihood method. $\mathrm{Q}_{(4)}$ and $\mathrm{Q}_{(4)}^{2}$ are the Ljung-Box test (1978) of significance of autocorrelations of four lags in the standardized and standardized squared residuals, respectively. $p_{\text {low,low }}$ and $p_{\text {high,high }}$ are the transition probabilities measuring the persistency of the low and high regimes, respectively.

Table A.6

Markov switching results - Kingdom of Saudi Arabia stock market.

\begin{tabular}{|c|c|c|c|c|c|c|c|c|c|c|c|c|}
\hline \multirow{2}{*}{$\begin{array}{l}\text { News from - > } \\
\text { Variable }\end{array}$} & \multicolumn{2}{|c|}{ Saudi Arabia } & \multicolumn{2}{|l|}{ Bahrain } & \multicolumn{2}{|l|}{ Kuwait } & \multicolumn{2}{|l|}{ Oman } & \multicolumn{2}{|l|}{ Qatar } & \multicolumn{2}{|l|}{ UAE } \\
\hline & Coeff. & Prob. & Coeff. & Prob. & Coeff. & Prob. & Coeff. & Prob. & Coeff. & Prob. & Coeff. & Prob. \\
\hline \multicolumn{13}{|l|}{ Regime low } \\
\hline$\mu^{l}$ & 0.042 & 0.070 & -0.067 & 0.512 & -0.031 & 0.701 & -0.013 & 0.875 & 0.110 & 0.033 & 0.092 & 0.075 \\
\hline Business news & -0.998 & 0.018 & 0.413 & 0.515 & 0.324 & 0.654 & 0.051 & 0.866 & -0.397 & 0.000 & -0.282 & 0.404 \\
\hline Political news & -0.066 & 0.156 & -0.042 & 0.817 & 0.550 & 0.461 & 0.398 & 0.676 & 0.005 & 0.336 & 0.196 & 0.096 \\
\hline$\sigma^{l}$ & 0.057 & 0.000 & 0.047 & 0.000 & 0.049 & 0.000 & 0.044 & 0.000 & 0.045 & 0.000 & 0.055 & 0.000 \\
\hline \multicolumn{13}{|l|}{ Regime high } \\
\hline$\mu^{h}$ & 0.112 & 0.039 & 0.053 & 0.045 & 0.106 & 0.046 & 0.129 & 0.024 & 0.125 & 0.181 & 0.276 & 0.013 \\
\hline Business news & -0.042 & 0.104 & 0.238 & 0.546 & -0.101 & 0.791 & -0.046 & 0.509 & -0.982 & 0.100 & -4.081 & 0.014 \\
\hline Political news & -0.104 & 0.188 & -0.019 & 0.185 & -0.056 & 0.594 & -0.007 & 0.791 & -0.952 & 0.090 & -0.398 & 0.360 \\
\hline$\sigma^{h}$ & 0.081 & 0.000 & 0.087 & 0.000 & 0.081 & 0.000 & 0.061 & 0.000 & 0.056 & 0.000 & 0.068 & 0.000 \\
\hline \multicolumn{13}{|l|}{ Control variables } \\
\hline $\mathrm{r}_{t-1}$ & 0.194 & 0.000 & 0.198 & 0.000 & 0.193 & 0.000 & 0.161 & 0.000 & 0.154 & 0.000 & 0.147 & 0.000 \\
\hline $\mathrm{r}_{t-2}$ & -0.085 & 0.109 & -0.058 & 0.301 & -0.105 & 0.736 & -0.048 & 0.216 & -0.075 & 0.207 & -0.054 & 0.291 \\
\hline Oil & 0.254 & 0.000 & 0.221 & 0.000 & 0.255 & 0.000 & 0.239 & 0.000 & 0.248 & 0.000 & 0.247 & 0.000 \\
\hline VIX & -0.013 & 0.000 & -0.085 & 0.000 & -0.017 & 0.000 & -0.064 & 0.000 & -0.012 & 0.000 & -0.166 & 0.000 \\
\hline KSA surprises & -0.059 & 0.000 & -0.108 & 0.000 & -0.058 & 0.000 & -0.096 & 0.000 & -0.060 & 0.000 & -0.098 & 0.000 \\
\hline KSA interest & -0.031 & 0.000 & -0.038 & 0.000 & -0.031 & 0.000 & -0.039 & 0.000 & -0.032 & 0.000 & -0.037 & 0.000 \\
\hline \multicolumn{13}{|c|}{ Transition matrix parameters } \\
\hline$p_{\text {low,low }}$ & 0.963 & 0.000 & 0.955 & 0.000 & 0.945 & 0.000 & 0.944 & 0.000 & 0.952 & 0.000 & 0.943 & 0.000 \\
\hline$p_{\text {high,high }}$ & 0.922 & 0.000 & 0.895 & 0.000 & 0.905 & 0.000 & 0.934 & 0.000 & 0.918 & 0.000 & 0.949 & 0.000 \\
\hline $\mathrm{Q}_{(4)}$ & 0.272 & & 0.464 & & 0.311 & & 0.544 & & 0.257 & & 0.440 & \\
\hline $\mathrm{Q}_{(4)}^{2}$ & 2.665 & & 2.797 & & 3.097 & & 3.862 & & 3.774 & & 4.071 & \\
\hline Log-lik & 506.765 & & 430.342 & & 491.730 & & 483.592 & & 410.928 & & 483.394 & \\
\hline
\end{tabular}

Note: See notes Table A.5. 
Table A.7

Markov switching results - Kuwait stock market.

\begin{tabular}{|c|c|c|c|c|c|c|c|c|c|c|c|c|}
\hline \multirow{2}{*}{$\begin{array}{l}\text { News from - > } \\
\text { Variable }\end{array}$} & \multicolumn{2}{|l|}{ Kuwait } & \multicolumn{2}{|l|}{ Bahrain } & \multicolumn{2}{|l|}{ KSA } & \multicolumn{2}{|l|}{ Oman } & \multicolumn{2}{|l|}{ Qatar } & \multicolumn{2}{|l|}{ UAE } \\
\hline & Coeff. & Prob. & Coeff. & Prob. & Coeff. & Prob. & Coeff. & Prob. & Coeff. & Prob. & Coeff. & Prob. \\
\hline \multicolumn{13}{|l|}{ Regime low } \\
\hline$\mu^{l}$ & 0.041 & 0.040 & 0.025 & 0.645 & 0.037 & 0.049 & 0.037 & 0.005 & 0.046 & 0.039 & 0.051 & 0.025 \\
\hline Business news & -0.043 & 0.753 & -0.055 & 0.280 & -0.257 & 0.078 & -0.288 & 0.463 & -0.143 & 0.305 & -0.358 & 0.055 \\
\hline Political news & 0.018 & 0.492 & 0.007 & 0.568 & 0.141 & 0.749 & 0.055 & 0.410 & -0.065 & 0.181 & 0.071 & 0.259 \\
\hline$\sigma^{l}$ & 0.042 & 0.000 & 0.031 & 0.000 & 0.042 & 0.000 & 0.041 & 0.000 & 0.036 & 0.000 & 0.037 & 0.000 \\
\hline \multicolumn{13}{|l|}{ Regime high } \\
\hline$\mu^{h}$ & 0.056 & 0.028 & 0.032 & 0.049 & 0.045 & 0.337 & 0.047 & 0.049 & 0.148 & 0.015 & 0.086 & 0.201 \\
\hline Business news & -0.997 & 0.314 & -0.241 & 0.028 & -0.982 & 0.012 & -0.180 & 0.102 & -0.985 & 0.034 & -0.476 & 0.045 \\
\hline Political news & 0.355 & 0.464 & 0.044 & 0.161 & 0.784 & 0.004 & -0.103 & 0.473 & -0.348 & 0.056 & 0.040 & 0.058 \\
\hline$\sigma^{h}$ & 0.048 & 0.000 & 0.051 & 0.000 & 0.047 & 0.000 & 0.048 & 0.000 & 0.045 & 0.000 & 0.045 & 0.000 \\
\hline \multicolumn{13}{|l|}{ Control variables } \\
\hline $\mathrm{r}_{t-1}$ & 0.331 & 0.000 & 0.384 & 0.000 & 0.339 & 0.000 & 0.309 & 0.000 & 0.357 & 0.000 & 0.375 & 0.000 \\
\hline $\mathrm{r}_{t-2}$ & -0.032 & 0.537 & -0.051 & 0.386 & -0.056 & 0.321 & 0.023 & 0.664 & -0.143 & 0.527 & -0.062 & 0.243 \\
\hline Oil & 0.038 & 0.001 & 0.139 & 0.000 & 0.228 & 0.000 & 0.274 & 0.000 & 0.250 & 0.000 & 0.261 & 0.000 \\
\hline VIX & -0.065 & 0.000 & -0.026 & 0.000 & -0.064 & 0.000 & -0.077 & 0.000 & -0.087 & 0.000 & -0.066 & 0.000 \\
\hline Kuw. surprises & 0.023 & 0.000 & 0.031 & 0.000 & 0.010 & 0.003 & 0.007 & 0.026 & 0.017 & 0.000 & 0.013 & 0.000 \\
\hline Kuw. interest & -0.025 & 0.000 & -0.033 & 0.000 & -0.079 & 0.000 & -0.036 & 0.018 & -0.055 & 0.001 & -0.042 & 0.000 \\
\hline \multicolumn{13}{|c|}{ Transition matrix parameters } \\
\hline$p_{\text {low, low }}$ & 0.923 & 0.000 & 0.951 & 0.000 & 0.929 & 0.000 & 0.932 & 0.000 & 0.943 & 0.000 & 0.922 & 0.000 \\
\hline$p_{\text {high,high }}$ & 0.934 & 0.000 & 0.897 & 0.000 & 0.904 & 0.000 & 0.899 & 0.000 & 0.908 & 0.000 & 0.905 & 0.000 \\
\hline $\mathrm{Q}_{(4)}$ & 0.309 & & 0.475 & & 0.468 & & 0.489 & & 0.507 & & 0.302 & \\
\hline $\mathrm{Q}_{(4)}^{2}$ & 2.065 & & 2.667 & & 3.109 & & 3.211 & & 3.443 & & 3.653 & \\
\hline Log-lik & 373.75 & & 338.62 & & 391.752 & & 375.823 & & 377.831 & & 384.415 & \\
\hline
\end{tabular}

Note: See notes Table A.5.

Table A.8

Markov switching results - Oman stock market.

\begin{tabular}{|c|c|c|c|c|c|c|c|c|c|c|c|c|}
\hline \multirow{2}{*}{$\begin{array}{l}\text { News from - > } \\
\text { Variable }\end{array}$} & \multicolumn{2}{|l|}{ Oman } & \multicolumn{2}{|l|}{ Bahrain } & \multicolumn{2}{|l|}{ KSA } & \multicolumn{2}{|l|}{ Kuwait } & \multicolumn{2}{|l|}{ Qatar } & \multicolumn{2}{|l|}{ UAE } \\
\hline & Coeff. & Prob. & Coeff. & Prob. & Coeff. & Prob. & Coeff. & Prob. & Coeff. & Prob. & Coeff. & Prob. \\
\hline \multicolumn{13}{|l|}{ Regime low } \\
\hline$\mu^{l}$ & -0.112 & 0.343 & -0.087 & 0.090 & -0.123 & 0.229 & -0.043 & 0.259 & 0.078 & 0.037 & 0.034 & 0.000 \\
\hline Business news & 0.338 & 0.873 & -0.230 & 0.044 & -0.972 & 0.048 & 0.092 & 0.476 & -0.451 & 0.040 & -0.164 & 0.009 \\
\hline Political news & 0.832 & 0.258 & 0.042 & 0.145 & 0.934 & 0.001 & -0.906 & 0.177 & -0.102 & 0.706 & 0.079 & 0.295 \\
\hline$\sigma^{l}$ & 0.052 & 0.000 & 0.042 & 0.000 & 0.043 & 0.000 & 0.046 & 0.000 & 0.041 & 0.000 & 0.049 & 0.000 \\
\hline \multicolumn{13}{|l|}{ Regime high } \\
\hline$\mu^{h}$ & 0.012 & 0.743 & 0.041 & 0.000 & 0.065 & 0.032 & 0.041 & 0.076 & 0.092 & 0.124 & 0.112 & 0.000 \\
\hline Business news & -0.264 & 0.203 & -0.175 & 0.004 & -0.359 & 0.047 & 0.197 & -0.102 & -0.495 & 0.042 & -0.938 & 0.787 \\
\hline Political news & -0.008 & 0.545 & -0.007 & 0.633 & -0.072 & 0.517 & -0.035 & 0.270 & -0.110 & 0.114 & 0.033 & 0.419 \\
\hline$\sigma^{h}$ & 0.076 & 0.000 & 0.071 & 0.000 & 0.075 & 0.000 & 0.053 & 0.000 & 0.063 & 0.000 & 0.062 & 0.000 \\
\hline \multicolumn{13}{|l|}{ Control variables } \\
\hline $\mathrm{r}_{t-1}$ & 0.453 & 0.000 & 0.401 & 0.000 & 0.421 & 0.000 & 0.431 & 0.000 & 0.412 & 0.000 & 0.381 & 0.000 \\
\hline $\mathrm{r}_{t-2}$ & -0.204 & 0.000 & -0.251 & 0.005 & -0.179 & 0.000 & -0.231 & 0.000 & -0.451 & 0.000 & -0.171 & 0.000 \\
\hline Oil & 0.019 & 0.944 & 0.048 & 0.000 & 0.032 & 0.000 & 0.031 & 0.000 & 0.026 & 0.000 & 0.034 & 0.000 \\
\hline VIX & -0.093 & 0.056 & 0.045 & 0.000 & 0.074 & 0.000 & 0.081 & 0.000 & -0.053 & 0.789 & 0.074 & 0.787 \\
\hline Oman surprises & 0.059 & 0.017 & -0.029 & 0.000 & -0.021 & 0.000 & -0.020 & 0.000 & -0.026 & 0.000 & -0.030 & 0.419 \\
\hline Oman interest & -0.112 & 0.000 & -0.159 & 0.000 & -0.105 & 0.000 & -0.167 & 0.000 & -0.185 & 0.001 & -0.098 & 0.000 \\
\hline \multicolumn{13}{|c|}{ Transition matrix parameters } \\
\hline$p_{\text {low,low }}$ & 0.711 & 0.021 & 0.732 & 0.021 & 0.713 & 0.099 & 0.721 & 0.043 & 0.734 & 0.015 & 0.728 & 0.011 \\
\hline$p_{\text {high,high }}$ & 0.798 & 0.092 & 0.702 & 0.324 & 0.798 & 0.218 & 0.778 & 0.124 & 0.708 & 0.209 & 0.797 & 0.204 \\
\hline
\end{tabular}


Table A.8 (continued)

\begin{tabular}{|c|c|c|c|c|c|c|c|c|c|c|c|c|}
\hline \multirow{2}{*}{$\begin{array}{l}\text { News from - > } \\
\text { Variable }\end{array}$} & \multicolumn{2}{|l|}{ Oman } & \multicolumn{2}{|l|}{ Bahrain } & \multicolumn{2}{|l|}{ KSA } & \multicolumn{2}{|l|}{ Kuwait } & \multicolumn{2}{|l|}{ Qatar } & \multicolumn{2}{|l|}{ UAE } \\
\hline & Coeff. & Prob. & Coeff. & Prob. & Coeff. & Prob. & Coeff. & Prob. & Coeff. & Prob. & Coeff. & Prob. \\
\hline $\mathrm{Q}_{(4)}$ & 0.642 & & 0.379 & & 0.260 & & 0.212 & & 0.375 & & 0.256 & \\
\hline $\mathrm{Q}_{(4)}^{2}$ & 2.998 & & 3.008 & & 3.225 & & 3.674 & & 4.097 & & 4.432 & \\
\hline Log-lik & 355.808 & & 353.033 & & 366.787 & & 399.777 & & 383.571 & & 356.402 & \\
\hline
\end{tabular}

Note: See notes Table A.5.

Table A.9

Markov switching results - Qatar stock market.

\begin{tabular}{|c|c|c|c|c|c|c|c|c|c|c|c|c|}
\hline \multirow{2}{*}{$\begin{array}{l}\text { News from - > } \\
\text { Variable }\end{array}$} & \multicolumn{2}{|l|}{ Qatar } & \multicolumn{2}{|l|}{ Bahrain } & \multicolumn{2}{|l|}{ KSA } & \multicolumn{2}{|l|}{ Kuwait } & \multicolumn{2}{|l|}{ Oman } & \multicolumn{2}{|l|}{ UAE } \\
\hline & Coeff. & Prob. & Coeff. & Prob. & Coeff. & Prob. & Coeff. & Prob. & Coeff. & Prob. & Coeff. & Prob. \\
\hline \multicolumn{13}{|l|}{ Regime low } \\
\hline$\mu^{l}$ & 0.158 & 0.000 & 0.041 & 0.401 & 0.043 & 0.120 & 0.081 & 0.029 & 0.041 & 0.420 & 0.148 & 0.000 \\
\hline Business news & -1.150 & 0.002 & -0.051 & 0.826 & -0.782 & 0.093 & 0.050 & 0.464 & -0.064 & 0.809 & -1.365 & 0.002 \\
\hline Political news & 0.021 & 0.199 & 0.014 & 0.617 & 1.138 & 0.014 & 0.135 & 0.123 & 0.191 & 0.216 & 0.046 & 0.626 \\
\hline$\sigma^{l}$ & 0.052 & 0.000 & 0.063 & 0.000 & 0.069 & 0.000 & 0.058 & 0.000 & 0.061 & 0.000 & 0.060 & 0.000 \\
\hline \multicolumn{13}{|l|}{ Regime high } \\
\hline$\mu^{h}$ & 0.191 & 0.000 & 0.061 & 0.117 & 0.119 & 0.003 & 0.105 & 0.026 & 0.065 & 0.112 & 0.175 & 0.012 \\
\hline Business news & -1.939 & 0.005 & 0.058 & 0.825 & -0.664 & 0.036 & -0.986 & 0.039 & -0.038 & 0.825 & -2.050 & 0.026 \\
\hline Political news & -0.159 & 0.399 & 0.007 & 0.530 & 0.011 & 0.406 & 0.029 & 0.893 & 0.033 & 0.502 & 0.181 & 0.533 \\
\hline$\sigma^{h}$ & 0.071 & 0.000 & 0.074 & 0.000 & 0.082 & 0.000 & 0.075 & 0.000 & 0.078 & 0.000 & 0.081 & 0.000 \\
\hline \multicolumn{13}{|l|}{ Control variables } \\
\hline $\mathrm{r}_{t-1}$ & 0.247 & 0.000 & 0.335 & 0.000 & 0.273 & 0.000 & 0.286 & 0.000 & 0.343 & 0.000 & 0.267 & 0.000 \\
\hline $\mathrm{r}_{t-2}$ & -0.116 & 0.021 & -0.114 & 0.042 & -0.114 & 0.032 & -0.131 & 0.000 & -0.131 & 0.000 & -0.101 & 0.000 \\
\hline Oil & 0.099 & 0.000 & 0.004 & 0.866 & 0.069 & 0.000 & 0.147 & 0.000 & 0.051 & 0.161 & 0.093 & 0.000 \\
\hline VIX & -0.080 & 0.000 & -0.074 & 0.000 & -0.033 & 0.000 & -0.020 & 0.000 & -0.070 & 0.000 & -0.015 & 0.000 \\
\hline Qatar surprises & -0.029 & 0.000 & 0.016 & 0.117 & 0.012 & 0.143 & -0.029 & 0.000 & 0.000 & 0.982 & -0.036 & 0.000 \\
\hline Qatar interest & -0.032 & 0.000 & -0.033 & 0.000 & -0.033 & 0.000 & -0.038 & 0.000 & -0.036 & 0.000 & -0.036 & 0.000 \\
\hline \multicolumn{13}{|c|}{ Transition matrix parameters } \\
\hline$p_{\text {low,low }}$ & 0.944 & 0.000 & 0.947 & 0.000 & 0.936 & 0.000 & 0.941 & 0.000 & 0.939 & 0.000 & 0.952 & 0.000 \\
\hline$p_{\text {high,high }}$ & 0.909 & 0.000 & 0.899 & 0.000 & 0.921 & 0.000 & 0.911 & 0.000 & 0.907 & 0.000 & 0.928 & 0.000 \\
\hline $\mathrm{Q}_{(4)}$ & 0.271 & & 0.249 & & 0.286 & & 0.224 & & 0.259 & & 0.274 & \\
\hline $\mathrm{Q}_{(4)}^{2}$ & 3.332 & & 4.221 & & 4.452 & & 3.775 & & 3.412 & & 3.078 & \\
\hline Log-lik & 389.135 & & 390.684 & & 399.105 & & 408.811 & & 386.710 & & 426.600 & \\
\hline
\end{tabular}

Note: See notes Table A.5.

Table A.10

Markov switching results - UAE (Abu Dhabi) stock market.

\begin{tabular}{|c|c|c|c|c|c|c|c|c|c|c|c|c|}
\hline \multirow{2}{*}{$\begin{array}{l}\text { News from - > } \\
\text { Variable }\end{array}$} & \multicolumn{2}{|l|}{ UAE } & \multicolumn{2}{|l|}{ Bahrain } & \multicolumn{2}{|l|}{ Kuwait } & \multicolumn{2}{|l|}{ KSA } & \multicolumn{2}{|l|}{ Oman } & \multicolumn{2}{|l|}{ Qatar } \\
\hline & Coeff. & Prob. & Coeff. & Prob. & Coeff. & Prob. & Coeff. & Prob. & Coeff. & Prob. & Coeff. & Prob. \\
\hline \multicolumn{13}{|l|}{ Regime low } \\
\hline$\mu^{l}$ & 0.168 & 0.001 & 0.064 & 0.000 & 0.082 & 0.194 & 0.093 & 0.084 & 0.048 & 0.446 & 0.112 & 0.006 \\
\hline Business news & -0.185 & 0.142 & -0.085 & 0.238 & -0.147 & 0.131 & -0.457 & 0.093 & 0.491 & 0.950 & -0.194 & 0.619 \\
\hline Political news & -0.077 & 0.110 & -0.019 & 0.294 & 0.002 & 0.941 & 0.023 & 0.003 & 0.217 & 0.632 & 0.014 & 0.614 \\
\hline$\sigma^{l}$ & 0.047 & 0.000 & 0.048 & 0.000 & 0.066 & 0.000 & 0.047 & 0.000 & 0.049 & 0.000 & 0.048 & 0.000 \\
\hline \multicolumn{13}{|l|}{ Regime high } \\
\hline$\mu^{h}$ & 0.234 & 0.005 & 0.103 & 0.120 & 0.108 & 0.000 & 0.101 & 0.003 & 0.118 & 0.003 & 0.219 & 0.005 \\
\hline Business news & -0.311 & 0.047 & -0.032 & 0.826 & -0.497 & 0.263 & -0.275 & 0.061 & -0.158 & 0.497 & -0.998 & 0.010 \\
\hline Political news & 0.088 & 0.279 & 0.006 & 0.853 & 0.213 & 0.212 & 0.029 & 0.043 & -0.012 & 0.059 & 0.092 & 0.794 \\
\hline$\sigma^{h}$ & 0.079 & 0.000 & 0.078 & 0.000 & 0.076 & 0.000 & 0.074 & 0.000 & 0.082 & 0.000 & 0.085 & 0.000 \\
\hline
\end{tabular}


Table A.10 (continued)

\begin{tabular}{|c|c|c|c|c|c|c|c|c|c|c|c|c|}
\hline \multirow{2}{*}{$\begin{array}{l}\text { News from - > } \\
\text { Variable }\end{array}$} & \multicolumn{2}{|l|}{ UAE } & \multicolumn{2}{|l|}{ Bahrain } & \multicolumn{2}{|l|}{ Kuwait } & \multicolumn{2}{|l|}{ KSA } & \multicolumn{2}{|l|}{ Oman } & \multicolumn{2}{|l|}{ Qatar } \\
\hline & Coeff. & Prob. & Coeff. & Prob. & Coeff. & Prob. & Coeff. & Prob. & Coeff. & Prob. & Coeff. & Prob. \\
\hline \multicolumn{13}{|l|}{ Control variables } \\
\hline $\mathrm{r}_{t-1}$ & 0.215 & 0.000 & 0.312 & 0.000 & 0.231 & 0.000 & 0.208 & 0.001 & 0.301 & 0.000 & 0.232 & 0.000 \\
\hline $\mathrm{r}_{t-2}$ & -0.029 & 0.117 & -0.003 & 0.358 & -0.018 & 0.671 & -0.051 & 0.237 & -0.047 & 0.462 & -0.021 & 0.618 \\
\hline Oil & 0.065 & 0.005 & 0.044 & 0.023 & 0.016 & 0.086 & 0.048 & 0.001 & 0.044 & 0.023 & 0.068 & 0.000 \\
\hline VIX & -0.044 & 0.000 & -0.046 & 0.000 & -0.084 & 0.000 & -0.038 & 0.000 & -0.061 & 0.000 & -0.042 & 0.000 \\
\hline UAE surprises & -0.267 & 0.000 & -0.260 & 0.000 & -0.198 & 0.000 & -0.260 & 0.000 & -0.258 & 0.000 & -0.272 & 0.000 \\
\hline UAE interest & -0.034 & 0.039 & -0.035 & 0.064 & -0.104 & 0.000 & -0.003 & 0.829 & -0.025 & 0.163 & -0.029 & 0.077 \\
\hline \multicolumn{13}{|c|}{ Transition matrix parameters } \\
\hline$p_{\text {low,low }}$ & 0.921 & 0.000 & 0.913 & 0.000 & 0.906 & 0.001 & 0.926 & 0.000 & 0.932 & 0.000 & 0.933 & 0.000 \\
\hline$p_{\text {high,high }}$ & 0.871 & 0.000 & 0.885 & 0.000 & 0.834 & 0.000 & 0.854 & 0.000 & 0.818 & 0.000 & 0.832 & 0.000 \\
\hline $\mathrm{Q}_{(4)}$ & 0.380 & & 0.369 & & 0.263 & & 0.455 & & 0.404 & & 0.366 & \\
\hline $\mathrm{Q}_{(4)}^{2}$ & 3.895 & & 3.393 & & 4.005 & & 4.525 & & 4.619 & & 3.911 & \\
\hline Log-lik & 544.556 & & 448.861 & & 478.692 & & 554.100 & & 446.299 & & 526.100 & \\
\hline
\end{tabular}

Note: See notes Table A.5.

Table A.11

Markov switching results - UAE (Dubai) stock market.

\begin{tabular}{|c|c|c|c|c|c|c|c|c|c|c|c|c|}
\hline \multirow{2}{*}{$\begin{array}{l}\text { News from - > } \\
\text { Variable }\end{array}$} & \multicolumn{2}{|l|}{ UAE } & \multicolumn{2}{|l|}{ Bahrain } & \multicolumn{2}{|l|}{ Kuwait } & \multicolumn{2}{|l|}{ KSA } & \multicolumn{2}{|l|}{ Oman } & \multicolumn{2}{|l|}{ Qatar } \\
\hline & Coeff. & Prob. & Coeff. & Prob. & Coeff. & Prob. & Coeff. & Prob. & Coeff. & Prob. & Coeff. & Prob. \\
\hline \multicolumn{13}{|l|}{ Regime low } \\
\hline$\mu^{l}$ & 0.237 & 0.000 & 0.121 & 0.260 & 0.161 & 0.106 & 0.172 & 0.105 & 0.133 & 0.217 & 0.239 & 0.000 \\
\hline Business news & -1.021 & 0.001 & -0.239 & 0.721 & 0.794 & 0.653 & -0.577 & 0.407 & 0.360 & 0.735 & -0.639 & 0.077 \\
\hline Political news & -0.097 & 0.245 & -0.051 & 0.887 & 0.774 & 0.102 & 0.084 & 0.091 & 0.786 & 0.726 & -0.148 & 0.213 \\
\hline$\sigma^{l}$ & 0.079 & 0.000 & 0.075 & 0.000 & 0.071 & 0.000 & 0.072 & 0.000 & 0.077 & 0.000 & 0.073 & 0.000 \\
\hline \multicolumn{13}{|l|}{ Regime high } \\
\hline$\mu^{l}$ & 0.406 & 0.000 & 0.155 & 0.003 & 0.203 & 0.000 & 0.229 & 0.000 & 0.161 & 0.009 & 0.359 & 0.000 \\
\hline Business news & -3.052 & 0.098 & -0.221 & 0.486 & -0.577 & 0.152 & -0.153 & 0.736 & -0.476 & 0.342 & -2.211 & 0.084 \\
\hline Political news & 0.237 & 0.273 & -0.085 & 0.368 & -0.111 & 0.315 & -0.355 & 0.164 & 0.087 & 0.479 & -0.075 & 0.842 \\
\hline$\sigma^{l}$ & 0.105 & 0.000 & 0.114 & 0.000 & 0.121 & 0.000 & 0.108 & 0.000 & 0.099 & 0.000 & 0.096 & 0.000 \\
\hline \multicolumn{13}{|l|}{ Control variables } \\
\hline $\mathrm{r}_{t-1}$ & 0.228 & 0.000 & 0.344 & 0.000 & 0.245 & 0.000 & 0.246 & 0.000 & 0.368 & 0.000 & 0.246 & 0.000 \\
\hline $\mathrm{r}_{t-2}$ & -0.043 & 0.095 & -0.012 & 0.746 & -0.052 & 0.265 & -0.609 & 0.409 & -0.076 & 0.212 & -0.023 & 0.320 \\
\hline Oil & 0.161 & 0.000 & 0.042 & 0.025 & 0.029 & 0.094 & 0.092 & 0.023 & 0.192 & 0.000 & 0.132 & 0.000 \\
\hline VIX & -0.063 & 0.000 & -0.091 & 0.000 & -0.071 & 0.000 & -0.051 & 0.000 & -0.096 & 0.000 & -0.096 & 0.000 \\
\hline UAE surprises & -0.400 & 0.000 & -0.361 & 0.000 & -0.360 & 0.000 & -0.381 & 0.000 & -0.354 & 0.000 & -0.330 & 0.000 \\
\hline UAE interest & -0.075 & 0.006 & -0.068 & 0.006 & -0.036 & 0.137 & -0.098 & 0.000 & -0.130 & 0.000 & -0.051 & 0.000 \\
\hline \multicolumn{13}{|c|}{ Transition matrix parameters } \\
\hline$p_{\text {low, low }}$ & 0.959 & 0.000 & 0.922 & 0.000 & 0.934 & 0.001 & 0.932 & 0.000 & 0.944 & 0.000 & 0.937 & 0.000 \\
\hline$p_{\text {high,high }}$ & 0.919 & 0.000 & 0.907 & 0.000 & 0.921 & 0.000 & 0.896 & 0.000 & 0.917 & 0.000 & 0.922 & 0.000 \\
\hline $\mathrm{Q}_{(4)}$ & 0.446 & & 0.396 & & 0.373 & & 0.485 & & 0.576 & & 0.286 & \\
\hline $\mathrm{Q}_{(4)}^{2}$ & 2.445 & & 3.671 & & 3.229 & & 4.006 & & 4.234 & & 3.887 & \\
\hline Log-lik & 407.562 & & 416.900 & & 396.145 & & 394.877 & & 434.406 & & 397.040 & \\
\hline
\end{tabular}

Note: See notes Table A.5.

\section{References}

Aday, S., Farrell, H., Lynch, M., Sides, J., Freelon, D., 2012. Blogs and Bullets II New Media and Conflict after the Arab Spring. United States Institute of Peace. Ahmed, S., 2011. The integration of financial markets in GCC countries. Pak. Dev. Rev. 209-2018.

Alfarano, S., Camacho, E., Morone, A., 2011. The Role of Public and Private Information in a Laboratory Financial Market. Working Paper.

Al-Kindi, A., 2016. GCC media roles during the 2011 Arab spring: an analytical and critical overview. J. Arts Soc. Sci.

Alodayni, S., 2016. Oil prices, credit risks in banking systems, and macro-financial linkages across GCC oil exporters. Int. J. Financ. Stud. 4 , 23. 
Andersen, T.G., Bollerslev, T., Diebold, F.X., Vega, C., 2007. Real-time price discovery in global stock, bond and foreign exchange markets. J. Int. Econ. 73, 251-277. Birz, G., Lott Jr., J.R., 2011. The effect of macroeconomic news on stock returns: new760 evidence from newspaper coverage. J. Bank. Finance 35 (11), 2791-2800. Caporale, G.M., Spagnolo, F., Spagnolo, N., 2016. Macro news and stock returns in the euro area: a VAR-GARCH-in-mean analysis. Int. Rev. Financ. Anal. 45, 180-188. Caporale, G.M., Spagnolo, F., Spagnolo, N., 2018a. Macro news and bond yield spreads in the euro area. Eur. J. Finance 24 (2), $114-134$.

Caporale, G.M., Spagnolo, F., Spagnolo, N., 2018b. Macro news and exchange rates in emerging markets. Res. Int. Bus. Finance 46, 516-552.

Chan, W.S., 2003. Stock price reaction to news and no-news: drift and reversal after headlines. J. Financ. Econ. 70, $223-260$.

Cutler, D., Poterba, J., Summers, L., 1989. What moves stock prices? J. Portf. Manag. 15, 56-63.

De Long, J., Shleifer, A., Summers, L.H., Waldmann, R., 1990. Positive feedback investment strategies and destabilizing rational speculation. J. Finance 45 (2), 379-395.

Hamilton, J.D., 1989. Analysis of time series subject to changes in regime. J. Econom. 45 (1) 39-70.780.

Hamilton, J.D., 1990. Time Series Analysis, vol. 2 Princeton University Press, Princeton.

Kim, C.J., Nelson, C.R., 1999. State-Space Models with Regime Switching: Classical and Gibbs-Sampling Approaches with Applications, vol. 2 MIT Press, Cambridge.

Lavrenko, V., Schmill, M., Lawrie, D., Ogilvie, P., Jensen, D., Allan, J., 2000. Language models for financial news recommendation. Proceedings of the 9th International Conference on Information and Knowledge Management (CIKM) 389-396.

Li, F., 2006. Do Stock Market Investors Understand the Risk Sentiment of Corporate Annual Reports? 54 Working Paper.

Ljung, G.M., Box, G.E.P., 1978. On a measure of lack of fit in time series models. Biometrika 65, 297-303.

Merton, R., 1973. An intertemporal capital asset pricing model. Econometrica 41 (5), 867-887.

Nartea, G.V., Ward, B.D., Djajadikerta, H.G., 2009. Size BM and momentum effects and the robustness of the Fama-French three-factor model: evidence from New Zealand. Int. J. Financ. Serv. Manag. 5, 179-200.

Schumaker, R.P., Zhang, Y.L., Huang, C.N., Chen, H., 2012. Evaluating sentiment in financial news articles. Decis. Support Syst. 53, $458-464$.

Shleifer, A., Vishny, R.W., 1997. The limits of arbitrage. J. Finance 52, 35-55.

Shkvarya, L., Frolova, Y., 2017. Transformations in socio-economic development of the Gulf group states. Econ. Region 1 (2), $570-578$.

Simpson, M.W., Ramchander, S., Chaudhry, M., 2005. The impact of macroeconomic surprises on spot and forward foreign exchange markets. J. Int. Money Finance 24, 693-718.

Strycharz, J., Strauss, N., Trilling, D., 2018. The role of media coverage in explaining stock market fluctuations: insights for strategic financial communication. Int. J. Strateg. Commun. 67-85.

Tetlock, P.C., 2007. Giving content to investor sentiment: the role of media in the stock market. J. Finance 62 (3), 1139-1169. https://doi.org/10.1111/j.1540-6261. 2007.01232.x

Tetlock, P.C., Saar-Tsechansky, M., Macskassy, S., 2008. More than words: quantifying language to measure firms' fundamentals. J. Finance 63, $1437-1467$.

Veronesi, P., 1999. Stock market overreactions to bad news in good times: a rational expectations equilibrium model. Rev. Financ. Stud. 12 (5), $975-1007$.

Wang, Y.-M., Li, C.-A., Lin, C.-F., 2009. The impact of investor sentiment on the futures market: evidence from the Taiwan futures exchange. Int. Res. J. Finance Econ. 28, 116-132. 